5-1-2005

\title{
The Legality of Humanitarian Intervention
}

\author{
Eric Adjei \\ University of Georgia School of Law
}

\section{Repository Citation}

Adjei, Eric, "The Legality of Humanitarian Intervention" (2005). LLM Theses and Essays. 2.

https://digitalcommons.law.uga.edu/stu_Ilm/2

This Article is brought to you for free and open access by the Student Works and Organizations at Digital Commons @ University of Georgia School of Law. It has been accepted for inclusion in LLM Theses and Essays by an authorized administrator of Digital Commons @ University of Georgia School of Law. Please share how you have benefited from this access For more information, please contact tstriepe@uga.edu. 


\title{
THE LEGALITY OF HUMANITARIAN INTERVENTION
}

by

\section{ERIC ADJEI}

(Under the Direction of Daniel Bodansky)

\begin{abstract}
Intervention in the domestic affairs of sovereign states by other sovereign state(s) is one of the 'hot' issues in international law today. The issue is 'hot' because the concept of human rights is on the ascendancy whilst international law had from time immemorial held the concept of sovereignty and its key feature, the principle of non-interference in high esteem. In fact, the concept of sovereignty has long been regarded as the bedrock of international relations. However, the doctrine of unilateral humanitarian intervention allows state(s) to intervene in the domestic affairs of sovereign states in the event of massive human rights violations, usually in the form of mass murders and genocide. The doctrine of humanitarian intervention, therefore, is an affront to one of the core principles of international law, namely, "non-interference" and as such its validity is hotly contested. This paper examines the legality of the doctrine of unilateral humanitarian intervention.
\end{abstract}

INDEX WORDS: Humanitarian Intervention, United Nations Charter, Customary International Law, Thesis, Graduate School, Student, LL.M Degree, The University Of Georgia. 


\title{
THE LEGALITY OF HUMANITARIAN INTERVENTION
}

\author{
by \\ ERIC ADJEI \\ LL.B., The University of Ghana, (Ghana) 1997 \\ Q.C.L., The Ghana Law School, (Ghana) 2002
}

\begin{abstract}
A Thesis Submitted to the Graduate Faculty of The University of Georgia in Partial Fulfillment of the Requirements for the Degree
\end{abstract}

MASTER OF LAWS

ATHENS, GEORGIA

2005 
(C) 2005

Eric Adjei

All Rights Reserved 


\section{THE LEGALITY OF HUMANITARIAN INTERVENTION}

by

ERIC ADJEI

$\begin{array}{ll}\text { Major Professor: } & \text { Daniel Bodansky } \\ \text { Reading Chair: } & \text { Gabriel M. Wilner } \\ \text { Committee: } & \begin{array}{l}\text { Gabriel M. Wilner } \\ \text { Daniel Bodansky }\end{array}\end{array}$

Electronic Version Approved:

Maureen Grasso

Dean of the Graduate School

The University of Georgia

May 2005 


\section{DEDICATION}

To God for taking me this far in my academic career

To my family for their unflinching love and support

To my friends for their encouragement 


\section{ACKNOWLEDGEMENTS}

I would like to express my sincere gratitude to Professor Daniel Bodansky for taking time from his busy schedule to supervise this thesis. I thank him for treating this thesis with the urgency that it deserved each time he had to go through. I also thank him for the pertinent suggestions he gave me. I'm most grateful to him.

I would also like to thank Professor Gabriel M. Wilner for all he’s done for me during my stay here in the University of Georgia. He’s been a wonderful teacher, father, and a great friend. I thank him for all his support and assistance each time it was needed. I also thank him for the wonderful work he’s doing for the LL.M program as a whole.

I would also like to thank Folasade Ogunmekan for being a wonderful friend, for giving me a helping hand each time I needed one. I owe her a debt of gratitude indeed.

Finally, I thank all members of the LL.M class of 2005 for their support in diverse ways. I've learnt a lot from their diverse backgrounds and I'm grateful to them for giving me that opportunity. I’m grateful to all of you. 
TABLE OF CONTENTS

Page

ACKNOWLEDGEMENTS ...............................................................

CHAPTER

1 INTRODUCTION ................................................................. 1

2 SOVEREIGNTY AND HUMANITARIAN INTERVENTION................... 4 STATE SOVEREIGNTY AND THE PRINCIPLE OF

NON -INTERVENTION .............................................. 4

DEFINITION OF UNILATERAL HUMANITARIAN

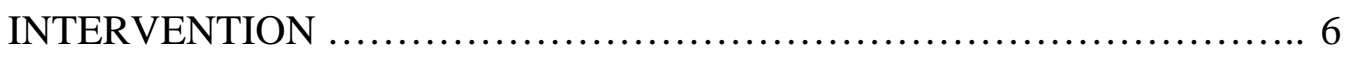

PURPOSES OF UNILATERAL HUMANITARIAN

INTERVENTION ........................................................ 8

HISTORICAL DEVELOPMENTS OF THE PRINCIPLE OF

UNILATERAL HUMANITARIAN INTERVENTION ...................... 11

3 TREATY LAW - UNITED NATIONS CHARTER........................... 24

TEXTUAL ARGUMENTS ............................................... 26

INTENT ARGUMENTS ................................................ 31

POLICY ARGUMENTS .................................................. 35

CONCLUSION: STATUS OF UNILATERAL HUMANITARIAN

INTERVENTION UNDER THE UNITED NATIONS CHARTER ............ 38 
4 CUSTOMARY INTERNATIONAL LAW ................................. 41

DEFINITION ................................................... 41

ELEMENTS OF CUSTOM .......................................... 41

STATE PRACTICE AFTER 1945 ...................................... 48

CONCLUSION: STATUS OF UNILATERAL HUMANITARIAN

INTERVENTION UNDER CUSTOMARY LAW .........................66

5 CONCLUSIONS .................................................... 68

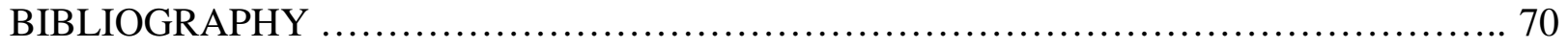




\section{CHAPTER 1}

\section{INTRODUCTION}

The doctrine of unilateral humanitarian intervention has been in existence and debated for the past several hundreds of years. However, the legality of this doctrine in international relations has always been subject to some debate because it is in direct conflict with one of the most fundamental norms in international relations, the principle of state sovereignty.

State sovereignty has, for the past several hundred years, been the defining principle of interstate relations and a foundation of world order. The concept finds expression at the roots of both customary law and the United Nations (UN) Charter. It remains one of the cardinal principles in international law and plays a pivotal role in the maintenance of world peace and order.

Perhaps, the singular most important attribute of the principle of state sovereignty is the principle of non-intervention, which denounces all forms of interference in the internal affairs of sovereign states. This principle postulates that each sovereign state should freely make its own choice in respect of the political and socio-economic policies, the culture to be adopted and so on. Briefly put, sovereignty means the independence, competence and legal equality of all states.

The doctrine of unilateral humanitarian intervention is of great importance in international law, and has grown in prominence in the last few decades. The term normally denotes an armed interference by one or several states in the internal affairs of another state, without its prior consent, in order to curtail gross human rights violations in the state. Unilateral 
humanitarian intervention, therefore, necessarily violates the sovereignty of the target state by interfering in the domestic affairs of the target state.

The doctrine of humanitarian intervention conflicts with one of the fundamental principles of international law. Therefore a clear legal justification is needed in order to warrant its continue use. The moral justification, de lege ferenda is not hard to find. However, the legal basis, de lege lata is very difficult to ascertain.

In contemporary times, the legality of this doctrine remains one of the most controversial issues in international law. Many governments and scholars are resolute in their belief that the United Nations (UN Charter), which regulates the use of force in international relations, prohibits all unilateral use of force, including humanitarian intervention. However, a growing number of scholars argue forcefully that unilateral humanitarian intervention is legal, or at least, a limited right exists.

In this dissertation I will assess the legality of unilateral humanitarian intervention in international law. I will examine the legality of the doctrine from two perspectives, first under the UN Charter and second, under Customary International Law since these are the two main sources of international law. It is important to state that the customary law rules on a subject could be different from that of treaties. This is important because the rules stipulated in a treaty are binding on only parties to that treaty but the rules of customary international law are generally binding on all states except states that objected to the rule during its development stages. Since the UN Charter is a treaty and binding on only members, it is essential to examine the customary law rules on unilateral humanitarian intervention after considering the rules stated in the UN Charter. I will refer to those scholars who postulate that unilateral humanitarian 
intervention is legal [under UN Charter] as the Realists, whilst those who posit that the doctrine is illegal as the Classicists.

Chapter 2 discusses the doctrine of humanitarian intervention, its definition, purposes, its evolution and status before the formation of the UN. It also examines 'humanitarian interventions' before the UN Charter. It concludes that a right of unilateral humanitarian intervention existed before the establishment of the UN.

Chapter 3 discusses the legality of unilateral humanitarian intervention under the UN Charter. It examines the provisions of the Charter on the use of force, espousing arguments by realists and classicists on the legality of the doctrine under the UN Charter. It examines textual arguments, intent arguments as well as policy arguments posited by realists and classicists. It concludes by noting that unilateral humanitarian intervention is not permitted by the UN Charter.

Chapter 4 discusses the rules regarding the formation of customary rules of international law. It examines whether the doctrine of unilateral humanitarian has evolved into a rule of customary international law. It concludes that unilateral humanitarian intervention is not a rule of customary international law. It is however admitted that there is ample evidence to the effect that unilateral humanitarian intervention is gradually developing into a rule of customary international law. Finally, I conclude that though the doctrine of unilateral humanitarian intervention is presently illegal under international law, it plays an important role in world affairs and should be permitted in situations of gross violations of human rights. However, clear criteria must be laid down to regulate the use of the doctrine in order to minimize the possibility of abuse. 


\section{CHAPTER 2}

\section{SOVEREIGNTY AND HUMANITARIAN INTERVENTION}

\section{STATE SOVEREIGNTY AND THE PRINCIPLE OF NON-INTERVENTION}

State sovereignty has been the defining principle of intestate relations and a foundation for world order for the past several hundreds of years. ${ }^{1}$ The concept is one of the fundamental principles of international law, both under the United Nations Charter (UN Charter) and customary international law, and plays an important role in the maintenance of international peace and security and a defense of weak states against the strong. ${ }^{2}$

State sovereignty refers to the competence, independence, and legal equality of states. ${ }^{3}$ Entailed in the concept are all matters in which each state is permitted by international law to decide and act without recourse to other sovereign states. ${ }^{4}$ Examples of such matters include the political system to be employed by the state as well as economic, cultural and social systems. ${ }^{5}$ In these matters, each state possesses the right to choose whichever system it prefers.

The concept of state sovereignty has been in existence for several centuries. However, a number of international law scholars agree that the present foundations of international law as it relates to sovereignty were highly influenced by the agreements reached by European states as part of the Treaties of Westphalia in $1648 .{ }^{6}$ The supremacy of the sovereign authority was

\footnotetext{
${ }^{1}$ See: The Report of the International Commission on Intervention and State Sovereignty at (http://www.iciss.ca/menu-en.asp).

${ }^{2}$ Id.

${ }^{3}$ Id.

${ }^{4}$ Id.

${ }^{5}$ Id.

${ }^{6}$ Francis Abiew, The Evolution of the Doctrine and Practice of Humanitarian Intervention 26-7 (The Hague: Kluwer, 1999); Louis Henkin, International Law: Politics and Values 9-10 (London: Martinus Nijihoff, 1995);
} 
established within a system of independent and equal states as a measure to avoid another war after nearly three decades of war, and thus establish peace and order in Europe. ${ }^{7}$

It is pertinent to know the essential elements of statehood because, for an entity to be entitled to sovereignty, that entity must qualify as a state. The Montevideo Convention laid down the essential elements of statehood. ${ }^{8}$ The main elements of statehood, as established by the Convention, include having a permanent population, a defined territory and a functioning government.

The United Nations Charter recognized state sovereignty as one of the fundamental principles of international law. The Charter accordingly adopted the principle of the sovereign equality of all states. ${ }^{9}$ Flowing from the importance of the principle of the sovereign equality of all states, the Charter sought to prohibit interference in the domestic affairs of sovereign states by other sovereign states, especially the threat or use of force. ${ }^{10}$ The Charter went further in its desire to promote the sovereignty of states by stating that "[n]othing contained in the present Charter shall authorize the United Nations to intervene in matters that are essentially within the domestic jurisdiction of any State or shall require the Members to submit such matters to settlement under the present Charter". ${ }^{11}$ Thus, not even the global body has the right to interfere in the domestic affairs of a sovereign state and therefore interfere in its enjoyment of its sovereign status.

The International Court of Justice (ICJ), the principal judicial organ of the United Nations, recognized the sanctity of the principle of non-interference in the domestic affairs of

Francis Hinsley, Sovereignty 126 (London: Basic Books, 1966); and Michael Reisman, "Sovereignty and Human Rights in Contemporary International Law,” 84 Am. J. Int'l L. 867 (1990).

${ }^{7}$ Stephen D. Krasner, “Compromising Westphalia”, 20 Int’l Sec. 115 (1995-6).

${ }^{8}$ See the 1933 Montevideo Convention on the Rights and Duties of States.

${ }^{9}$ U. N. Charter, art. 2(1).

${ }^{10}$ U. N. Charter, art. 2(4).

${ }^{11}$ U. N. Charter, art. 2(7). 
states. The Court noted in 1949 "between independent states, respect for territorial sovereignty is an essential foundation of international relations."12 Some three decades later, the ICJ observed that the principle of non-intervention was "the fundamental principle of state sovereignty on which the whole of international law rests.”13

Notwithstanding the importance and role of state sovereignty in international relations, the limit of the principle has always been in dispute, and remains so now. The present controversy emanates from the rise in the status of the principle of humanitarian intervention which is inconsistent with 'traditional' notions of sovereignty. As has been noted in the report of the International Commission on Intervention and State Sovereignty:

Few subjects in international law and international relations are as sensitive as the notion of sovereignty. Steinberger refers to it in the Encyclopedia of Public International Law as "the most glittering and controversial notion in the history, doctrine and practice of international law." On the other hand, Henkin seeks to banish it from our vocabulary and Lauterpacht calls it a "word which has an emotive quality lacking meaningful specific content," while Verzijl notes that any discussion on this subject risks degenerating into a Tower of Babel. More affirmatively, Brownlie sees sovereignty as "the basic constitutional doctrine of the law of the law nations" and Alan James sees it as "the one and only organising principle in respect of the dry surface of the globe, all that surface now... being divided among single entities of a sovereign or constitutionally independent kind.” As noted by Falk, "There is little neutral ground when it comes to sovereignty.",14

Despite the pivotal role of the concept of sovereignty in international relations, it has been facing some challenges, especially in the last quarter of the $20^{\text {th }}$ century.

\section{DEFINITION OF UNILATERAL HUMANITARIAN INTERVENTION}

Various scholars have defined intervention differently, and it is so with the concept of humanitarian intervention. ${ }^{15}$ Intervention has been defined broadly to include even verbal

\footnotetext{
${ }^{12}$ Asylum Case, ICJ Rep. (1949), 4.

${ }_{14}^{13}$ Nicaragua Case, ICJ Rep. (1986), para. 264.

14 See the report of the International Commission on Intervention and State Sovereignty at http://www.iciss.ca/menu-en.asp

${ }^{15}$ George R. Wright, A Contemporary Theory of Humanitarian Intervention, 4 Fla. Int'l L. J. 435 (1989).
} 
remarks of government actors concerning another state's affairs. ${ }^{16}$ On the other hand, some writers have defined it narrowly to include only "dictatorial interference by a state in the internal affairs of another state or in the relations between other states.”17

Customarily, when we refer to 'intervention', in international law, we refer to prohibited intervention. ${ }^{18}$ One could however distinguish between basically three forms of "intervention”, depending on the degree of coercion employed in order to influence other states. ${ }^{19}$ In the first place, “intervention” simply means discussion, examination, and the recommendatory action. ${ }^{20}$ Second, "intervention" refers to the taking of measures that are coercive in nature but short of the use of force. ${ }^{21}$ Finally, "intervention is used to refer to the use of force in the domestic affairs of another state. $^{22}$

Humanitarian intervention has been defined as the "justifiable use of force for the purpose of protecting the inhabitants of another state from treatment so arbitrary and persistently abusive as to exceed the limits within which the sovereign is presumed to act with reasons and justice."23 It has also been defined as "the theory of intervention on the ground of humanity... that recognizes the right of one state to exercise an international control by military force over the acts of another in regard to its internal sovereignty when contrary to the law of humanity."24 Teson, a contemporary international law scholar defines humanitarian intervention as " the proportionate transboundary help, including forcible help, provided by governments to

\footnotetext{
${ }^{16}$ Id.

${ }^{17}$ Id.

${ }^{18}$ Fernando R. Teson, Humanitarian Intervention 133 ( $2^{\text {nd }}$ ed. 1997).

${ }^{19}$ Id. at 135.

${ }^{20}$ Id.

${ }^{21}$ Id.

${ }^{22}$ Id.

${ }^{23}$ Ellery Stowell, International Law 349 (1931), quoted in Steve G. Simon, The Contemporary Legality of Humanitarian Intervention, 24 Cal. W. Int'l L. J. 117, 118 (1993).

${ }^{24}$ Steve G. Simon, The Contemporary Legality of Humanitarian Intervention, 24 Cal. W. Int'l L. J. 117, 118 (1993).
} 
individuals in another state who are being denied basic human rights and who themselves would be rationally willing to revolt against their oppressive government.”25

Although these definitions are not necessarily identical, they convey what the doctrine of humanitarian intervention entails. They shed light on significant factors that must be identified and understood in order to fully comprehend the issues involved in the doctrine. First, the use of armed force is a common feature of all the definitions. Thus, humanitarian intervention connotes rightly the use of military force in the internal affairs of a state by another state or group of states. Second, for there to be humanitarian intervention, the justification for the use force depends on human rights violations in the target state.

As stated by Teson, the customary meaning of prohibited intervention denotes “dictatorial interference in the affairs of another state for purposes of altering or maintaining the actual order of things" in a matter which is essentially within the discretion of the target state. ${ }^{26}$ Therefore, as rightly noted by Teson, for an intervention to be prohibited, the means used must be coercive and the ends of the intervention must be to influence another state's decision or conduct in a matter that is essentially within the domestic jurisdiction of that state. ${ }^{27}$

\section{PURPOSES OF HUMANITARIAN INTERVENTION}

\section{A. CURTAILING MASSIVE HUMAN RIGHTS VIOLATIONS}

One of the main reasons advocated for humanitarian interventions is the prevention of genocide and other mass murder of civilian populations by state actors against their own citizens. Since 1900, it is estimated that governments and political leaders have killed about 169,198,000

\footnotetext{
${ }^{25}$ Fernando R. Teson, Humanitarian Intervention: An inquiry into Law and Morality 5 (1988).

${ }^{26} \mathrm{Id}$.

${ }^{27}$ Id.
} 
of their own citizens. ${ }^{28}$ This number is by far greater than the lives lost during all the wars in this century. $^{29}$

Humanitarian interventions have been undertaken in order to curtail massive human rights abuses. The Idi Amin government of Uganda, during its reign from1971 to 1979, committed widespread atrocities and massive human rights violations against its own citizens ${ }^{30}$ and Amnesty International characterized the regime as atrocious after uncovering executions, rape and torture committed by the regime. ${ }^{31}$ Tanzania intervened in Uganda in 1979 for humanitarian reasons ${ }^{32}$ though it has been suggested that Tanzania had other primary reasons for the intervention. ${ }^{33}$

Similarly, India intervened in East Bengali (now Bangladesh) in order to curtail massive human rights violations. This was after the Pakistani Army had descended on the civilian populace of East Bengali in "an orgy of killing, terror, and destruction which led to the loss of at least one million lives. ${ }^{34}$ India’s intervention undoubtedly halted atrocities on a wide scale. India cited human rights violations of the West Pakistanis and transborder aggression by the Pakistani as reasons for the intervention. ${ }^{35}$ India's representative to the United Nations, in justifying the intervention stated thus: "we have ... absolutely nothing but the purest of motives and the purest of intentions: to rescue the people of East Bengal from what they are suffering." ${ }^{36}$ It has been

\footnotetext{
${ }^{28}$ Laura Geissler, The Law of Humanitarian Intervention and the Kosovo Crisis, 23 Hamline L. Rev. 323, 325 (2000).

${ }^{29}$ Id.

${ }^{30}$ Thomas M. Franck, Of Gnats and Camels: Is there a Double Standard at the United Nations? , 78 Am. J. Int'l L. 811, 825 (1984).

${ }^{31}$ Amnesty International, Human Rights in Uganda, Report, June 1978, Doc. AFR 59/05/78.

${ }^{32}$ Fernando R. Teson, Humanitarian Intervention: An Inquiry into Law and Morality 164 (1988).

${ }^{33}$ Ved P. Nanda, Tragedies in Northern Iraq, Liberia, Yugoslavia, and Haiti-Revisiting the Validity of Humanitarian Intervention under International Law-Part I. 20 Denv. J. Int'l L. 305, 320 (1992).

${ }^{34}$ Byron F. Burmester, On Humanitarian Intervention: The New World Order and Wars to Preserve Human Rights, 1994 Utah L. Rev. 269 (1994).

${ }_{35}$ Douglas Eisner, Humanitarian Intervention in the Post-Cold War Era, 11 B. U. Int'l L. J. 195, 202 (1993).

${ }^{36}$ Id.
} 
argued that India had other selfish motives for intervening in East Bengal, including splitting up and weakening a powerful rival and thus enhancing its own security. ${ }^{37}$ That notwithstanding, Bazyler asserts that India's “course of action in the Bangladesh situation probably constitutes the clearest case of forceful individual humanitarian intervention in this century," emphasizing the humanitarian nature of the intervention. ${ }^{38}$

Though most, if not all, of these interventions have been characterized as not genuine humanitarian interventions, the fact that humanitarian concerns offered part of the justification for the intervening states is not seriously doubted.

\section{B. MAINTAINING REGIONAL AND GLOBAL STABILITY}

Another espoused justification for humanitarian intervention is the maintenance of regional and global security. When one state becomes insecure, such as an occurrence of genocide, regional and global security is threatened. This is the result of refugees fleeing their home country to neighboring ones to save their lives. For example, the Indian intervention in East Bengal (now Bangladesh) could be attributed (at least partly) to the massive inflows of refugees to India from East Bengal as a result of the mass murders and other atrocities committed against the people of East Bengal by the Pakistan army. ${ }^{39}$ It is estimated that an approximately ten million East Bengalis fled to India, causing the country tremendous hardship. ${ }^{40}$

Again, the Organization of East Caribbean States (OECS) assisted the United States to intervene in Grenada in 1983. Grenada descended into chaos after the Grenadian People’s Revolutionary Army led a coup against Grenada’s government and killed Prime Minister

\footnotetext{
${ }^{37} \mathrm{Id}$.

${ }^{38}$ Michael J. Bazyler, Reexamining the Doctrine of Humanitarian Intervention in Light of the Atrocities in Kampuchea and Ethiopia, 23 Stan. J. Int'l L. 547, 589 (1987).

${ }^{39}$ A. C. Arend and R. J. Beck, International Law and the Use of Force 113-4 (London, Routledge, 1993).

${ }^{40}$ Douglas Eisner, Humanitarian Intervention in the Post-Cold War Era, 11 B. U. Int'l L. J. 195, 202 (1993).
} 
Maurice Bishop and three other officials. ${ }^{41}$ Though the United States led the operation apparently to rescue United States medical students in Grenada; the OECS found the civil strife and breakdown in government to constitute a security threat to their nations and resolved to use force to ensure peace. ${ }^{42}$ That provided the justification for the OECS assistance to the United States in the Grenada intervention.

Further, there is the tendency that dictators may think that they have become 'too powerful' and try to encroach on the sovereignty of neighboring countries. Hitler's regime in Germany thought it had grown so powerful and started attacking neighboring countries without just cause. The end result was World War II that devastated the world.

IV. HISTORICAL DEVELOPMENTS OF THE PRINCIPLE OF UNILATERAL HUMANITARIAN INTERVENTION

\section{A. THE LAW OF NATURE}

In the early development of western culture, Greek philosophers began arguing about the existence of a universal law of nature, which everybody was obliged to obey and all positive laws had to conform to. Aristotle (284-322 BC) made some fundamental assumptions about this natural law thus: "One part of what is politically just is natural, and the other part legal. What is natural is what has same validity everywhere alike."43

However, this theory was not developed further until much later when the Stoics developed a coherent theory about the Law of Nature. They saw the natural law as something that was part of the structure of the universe, and directed the actions of rational beings. They

\footnotetext{
${ }^{41}$ Ved P. Nanda, Tragedies in Northern Iraq, Liberia, Yugoslavia, and Haiti-Revisiting the Validity of Humanitarian Intervention under International Law-Part I. 20 Denv. J. Int'l L. 305, 322 (1992).

${ }^{42}$ John N. Moore, Grenada and the International Double Standard, 78 Am. J. Int'l L. 145, 148 (1984).

${ }^{43}$ Aristotle, The Ethics of Aristotle: The Nichomachean Ethics 20 (1953).
} 
thus believed that the Law of Nature was conceivable a priori, ${ }^{44}$ universal and applied to all individuals alike.

The Law of Nature was the philosophical underpinnings of several basic norms, both legal and moral. It is an essential feature of the Law of Nature that all human beings be treated equally ${ }^{45}$ and can therefore be regarded as the foundation of the concept of inherent human rights. This Law constituted the rational basis of political society and formed the foundation on which the social contract theory and state sovereignty were based in the early days of civilization.

\section{B. JUST WAR THEORIES}

The doctrine of humanitarian intervention is historically strongly tied to the moralpolitical theory of just war (bellum justum). The ancient Greeks opined that war must not be waged unless the cause for waging it was justified. The Christian church in its formative years was largely pacifist (anti-war) and refused to accept any justification for waging war, no matter the circumstance.

St. Augustine (354-430) was the first major theologian who postulated a theory of just war. Basically, he sought to reconcile the political reality of war with the Christian model of pacifism. He laid down a criterion that if met, would justify the waging of war. He relied on two key concepts, namely, a just cause and a right intention. Incidentally, these concepts formed the very basis of Christian moral theory existing at the time. It was imperative to ascertain the justness of an action by evaluating the intention behind the particular act. St. Augustine, writing on the legality of war, said: “Just wars are usually defined as those which avenge injuries, when

\footnotetext{
${ }^{44}$ That this law was conceivable by the mere exercise of reason, and everybody had the power of reason because God had endowed every human being with it. Every human being was therefore capable of conceiving the natural law.

${ }^{45}$ See generally Aristotle, The Ethics of Aristotle: The Nichomachean Ethics.
} 
the nation or city against which warlike action is to be directed has neglected either to punish wrongs committed by its own citizens or to restore what has been unjustly taken by it. Further, that kind of war is undoubtedly just which God Himself ordains”. ${ }^{46}$

Over time, Christian concepts became increasingly influential in the sphere of political theory. This led to the establishment and acceptance of the theory of bellum justum that became an essential foundation of the rules of war.

St. Thomas Aquinas (1225-74) sought to propound his own theory about just wars, but this was largely based on the model developed by St. Augustine. He laid less emphasis on pacifist commands from the bible that prohibited all wars whatsoever. He concluded that there is no general prohibition on war and that when certain requirements are met; a war could be waged justly.

First, it had to be waged by a competent authority, which authority he referred to as 'the authority of $[\mathrm{P}]$ rinces or of the $[\mathrm{C}]$ hurch. ${ }^{47}$ Second, there must be a just cause for the war, meaning, "that those who are attacked merit the attack because of some fault (culpa)., ${ }^{48}$ He gave examples of just wars as wars fought in self-defense; restoration of peace; assistance of neighbors against armed attack and most importantly, 'defense of the poor and oppressed' (emphasis added).$^{49}$ Finally, a just war had to be waged with a right intention.

Hugo Grotius, the man widely regarded as the father of international law was the first western philosopher who sought to separate the law of nature from the law of God. ${ }^{50}$ Perhaps Grotius' singular most important contribution to legal theory is his application of the concept of

\footnotetext{
${ }^{46}$ Peter Malanczuk, Akehurst's Modern Introduction to International Law, quoted in Dunoff et al, International Law: Norms, Actors, Process; A Problem Oriented Approach 827 (2002).

${ }^{47}$ Summa Theologica II, II, 188, para 4.

${ }^{48}$ Id II, II, 40, para 1.

${ }_{50}^{49}$ Id II, II, 188, para 3.

50 M. D. A. Freeman, Lloyd's Introduction to Jurisprudence 100 (London, Sweet \& Maxwell, $6^{\text {th }}$ ed. 1994).
} 
natural law to international law. He built his Law of Nations on his view of the Law of Nature. ${ }^{51}$ He argued that the individual possessed some inherent rights, emphasizing that nation-states came into existence because individuals wanted to improve their security and as a result ceded part of their inherent rights to the state. The sovereign powers of the state were therefore limited to the extent of the rights ceded by individuals.

Therefore, the state exceeded its authority when it denied individuals their basic rights that they had not ceded to the state. It follows that if the sovereign violated the basic rights of the people, he exceeded his jurisdiction and other states had the right to intervene and re-establish the order of the Law of Nature. He put it this way:

Certainly it is undoubted that ever since civil societies were formed, the rulers of each claimed some special rights over his own subjects. [But] ... if a tyrant practices atrocities towards his subjects, which no just man can approve, the right of human social connexion is not cut off in such a case. It would not follow that others may not take up arms for them. $^{52}$

The statement above and others by Grotius compelled Lauterpacht to state that perhaps Grotius was the first person to authoritatively state the principle of humanitarian intervention. Lauterpacht states: "Grotius [made] the first authoritative statement of the principle of humanitarian intervention - the principle that exclusiveness of domestic jurisdiction stops when outrage upon humanity begins.”53

Grotius was of the view that intention was irrelevant for the justice of war but considered in detail the justifiable means of waging war. ${ }^{54}$ He asserted that the issue of the justifiable means was contingent on the justifiability of the cause for waging the war. He propounded a theory of

\footnotetext{
${ }^{51}$ M. D. A. Freeman, Lloyd's Introduction to Jurisprudence 99 (London, Sweet \& Maxwell, $6{ }^{\text {th }}$ ed. 1994).

${ }_{53}^{52}$ Id II, XXV, para 6(3).

${ }^{53}$ H. Lauterpacht quoted in P. Malanczuk, Humanitarian Intervention and the Legitimacy of the Use of Force 7 (Amsterdam, Het Spinhuis, 1993).

${ }^{54}$ L.R.B. Walters, Five Classic Just -War Theories: A Study in the Thought of Thomas Aquinas, Victoria, Suarez, Gentili, and Grotius 353 (Michigan, University Films, 1971).
} 
proportionality, by holding that any means outside what is necessary for achieving the just cause, would be unjust: ${ }^{55}$ "The good which our action has in view [must be] much greater than the evil which is feared, unless, [when] the good and evil in balance, the hope of the good is much greater than the fear of the evil." ${ }^{, 56}$

Grotius concluded that certain actions were essentially prohibited no matter what the justification is. This included the killing of civilians that he considered to be the principal crime of war, the raping of women from the enemy side and the forcing of innocent people into slavery. ${ }^{57}$ He however pointed out that sometimes the necessities of war would result in a justifiable violation of the norms that he considered essentially prohibited:

Many things accompany the right of the agent indirectly and beyond the agent's intention. ... Thus in order to obtain what is ours, if we cannot get that alone, we have the right to take more. Similarly, we may bombard a ship full of pirates or a house full of thieves, even if there are within the same ship or house a few infants, women or other innocent persons. ${ }^{58}$

A survey of the views of the natural law thinkers in the $16^{\text {th }}$ and $17^{\text {th }}$ centuries indicate clearly that they considered humanitarian intervention as legal and an integral part of the doctrine of bellum justum and in conformity with the law of nature. Wars were not legal per se, but if the stated conditions were met, wars could legally be waged. Thus, natural law put certain limitations on the independence and sovereignty of states by holding that a state could intervene in the affairs of another if certain conditions existed.

\footnotetext{
${ }^{55}$ Id. 367-70.

${ }^{56}$ H. Grotius, De Jure Belli ac Pacis Prolegomena III, I, para 4 (2), (1625).

${ }^{57}$ L.R.B. Walters, Five Classic Just -War Theories: A Study in the Thought of Thomas Aquinas, Victoria, Suarez, Gentili, and Grotius (Michigan, University Films, 1971) 404 ff.

${ }^{58}$ H. Grotius, De Jure Belli ac Pacis Prolegomena, 1I1, I, para 4 (1), (1625).
} 


\section{TOWARDS A JUS AD BELLUM FOR THE SOVEREIGN STATE}

The views posited by Grotius led to a change in the paradigm of political and legal theory, shifting the emphasis away from the influence of Christian doctrine, resulting in a more realistic view of the theory of sovereignty and the law of war.

Machiavelli, a great 'political realist,' sought to write about politics as it was at the time and not as it ought to be. He realized that in renaissance Europe, the Princes did whatever suited them and there were no limitations on their power, internally and externally. He concluded that the sovereign did not have a moral superior; the moral good of the society is what the Prince considered it to be. In relation to war, he stated thus:

When it is a question of the safety of the country no account should be taken of what is just or unjust, merciful or cruel, laudable or shameful, but without regard to anything else, that course is to be unswervingly pursued which will save the life and pursue the liberty of the [fatherland]. ${ }^{59}$

Bodin was one of the first scholars to develop a coherent theory on the principle of sovereignty. He held a view similar to that of Machiavelli. He posited that the sovereign, as supreme legislator, was free from any restraints posed by positive law. ${ }^{60}$ The sovereignty of the nation-state was therefore virtually unlimited.

Hobbes, a predecessor of Bodin, was of the view that people had formed societies to protect them from anarchy. ${ }^{61}$ He posited that as long as the government protects the majority of the people, the people had to obey the laws unconditionally. This absolute sovereignty also applied externally; therefore no other state had the right to interfere with the sovereign's treatment of his own people.

\footnotetext{
${ }^{59}$ N. Machiavelli, The Prince (1513).

${ }^{60}$ F. K. Abiew, The Evolution of the Doctrine and Practice of Humanitarian Intervention 27 (Hague, Kluwer Law International, 1992). The sovereign had to respect natural law, divine law and jus gentium. However, in practice these did not constitute any serious restraint.

${ }^{61}$ M. D. A. Freeman, Lloyd's Introduction to Jurisprudence102 (London, Sweet \& Maxwell, $6^{\text {th }}$ ed. 1994).
} 
John Locke also agreed that the social contract was the foundation of society. Though, he argued from a somewhat weaker position of sovereignty, he nevertheless held that the sovereign held wide discretionary powers both externally and internally. ${ }^{62}$

It is significant to note that these theories of sovereignty were developed in light of the religious wars of the $16^{\text {th }}$ and $17^{\text {th }}$ centuries that had caused constant disorders in Europe. It is therefore not surprising that the principle of sovereignty got its legal confirmation in the treaty of Westphalia, which ended the thirty years of war. This treaty inaugurated the modern European state system and established the nation-state as the principal actor in international law. ${ }^{63}$

The treaty however put limited restraints on the sovereign's power, especially regarding the practice of religion, which was the dominant political issue. The Princes could determine the principal religion within their territory, but minorities had the freedom to practice whichever religion they chose. ${ }^{64}$ Thus, even the strict principle of sovereignty of the $17^{\text {th }}$ century had some important limitations.

It is significant to note that the theory of sovereignty that was developing in the $18^{\text {th }}$ and $19^{\text {th }}$ century differed fundamentally from that postulated in the teachings of Grotius. Notions such as 'justice' or 'humanity' did not restrict the sovereignty of the nation-state, and therefore humanitarian intervention could not be regarded as lawful. According to Brownlie, the concept of just war was relegated 'to the realms of morality and propaganda' ${ }^{65}$ Instead, as Vattel noted, a principle of non-intervention was developed:

It clearly follows from the liberty an independence of Nations that each has the right to govern itself as it thinks proper. ....No foreign State may enquire into the manner in

\footnotetext{
${ }^{62} \mathrm{Id}$.

${ }^{63}$ F. K. Abiew, The Evolution of the Doctrine and Practice of Humanitarian Intervention 29 (Hague, Kluwer Law International, 1992).

${ }^{64}$ Id. at 44-6.

${ }^{65}$ Ian Brownlie, International Law and the Use of Force by States 20 (Oxford, Clarendon Press, 1963).
} 
which a sovereign rules, nor set itself up as judge of his conduct, nor force him to make any change in his administration. ${ }^{66}$

Vattel, however, later made a modest change to this view when he recognized that under certain circumstances states may intervene in the affairs of each other. ${ }^{67}$ Other contemporary scholars recognized a limited right of intervention on humanitarian grounds. However, this was not in accordance with the legal and political realities of the time.

This does not mean war was considered illegal per se, but the justification for waging war was no longer found in a concept of justice. The justa causa had been replaced by a customary right to go to war in accordance with the virtually unlimited sovereignty enjoyed by States. ${ }^{68}$ States were thus said to have a competence de guerre. ${ }^{69}$ Thus, Kunz noted: "The concept of bellum legale replaced the concept of bellum justum."70

Therefore, in the $18^{\text {th }}$ and $19^{\text {th }}$ centuries, there was nearly a complete abandonment of the distinction between legal and illegal wars and war was generally justified if they were fought for the protection or defense of certain vital interests. ${ }^{71}$

\section{INTERVENTIONS IN THE $19^{\mathrm{TH}}$ AND EARLY $20^{\mathrm{TH}}$ CENTURIES}

Based on the strict application of the sovereignty of nation-states, the $19^{\text {th }}$ century was characterized by an unlimited right of war and the recognition of conquests. ${ }^{72}$ It was only the emergence of the balance-of-power system in the $19^{\text {th }}$ century curtailed wars to a very great

\footnotetext{
${ }^{66}$ E. de Vattel, Droit des Gens (1758) I, II, IV, para 54-5.

${ }^{67}$ F. K. Abiew, The Evolution of the Doctrine and Practice of Humanitarian Intervention 36 ff. (Hague, Kluwer Law International, 1992).

${ }^{68}$ A. C. Arend and R. J. Beck, International Law and the Use of Force (London, Routledge, 1993), 16

${ }^{69}$ Id. at 17.

${ }^{70}$ J.L. Kunz, Bellum Justum and Bellum Legale, 45 Am. J. Int'l L. 528, 532 (1951). That is, justice was no longer an element of the legal right to go to war.

${ }^{71}$ Peter Malanczuk, Akehurst's Modern Introduction to International Law, quoted in Dunoff et al, International Law: Norms, Actors, Process; A Problem Oriented Approach 828 (2002).

${ }^{72}$ Ian Brownlie, International Law and the Use of Force by States 19 (Oxford, Clarendon Press, 1963).
} 
extent. The expense, destructiveness and long duration of wars, coupled with the risks of defeat, meant that wars were not worth fighting unless the stakes involved were very high. ${ }^{73}$

In 1860, Philimore wrote that: "War is the exercise of the international right of action, to which, from the nature of the thing and the absence of any common superior tribunal, nations are compelled to have recourse, in order to assert and vindicate their rights."74

However, war was only regarded as a measure of last, and was to be resorted to only when all peaceful means to the resolution of a conflict failed. In 1878, the World Peace Conference in Paris declared by a resolution that: "la guerre offensive est un brigandige”. 75

State practice, however, did not immediately reflect the changes in the world's attitude to wars. Instead, what evolved was a doctrine of a right to 'self-preservation' of the nation-state, as a 'Droit absolut des Etats'. ${ }^{76}$ Out of this doctrine evolved a practice of lesser measures of armed force, which did not amount to 'war', such as 'self-defense',77 'reprisal' and 'pacific blockade'. 78

This practice of lesser measures of force eventually developed to include interventions justified on humanitarian grounds. This started with the invasion of Greece by some western powers in 1827 to protect Greek Christians from persecution by the occupying Turks. The Treaty

\footnotetext{
${ }^{73}$ Peter Malanczuk, Akehurst's Modern Introduction to International Law, quoted in Dunoff et al, International Law: Norms, Actors, Process; A Problem Oriented Approach 828 (2002).

${ }^{74}$ R. Phillimore, Commentaries upon International Law VIII, 77 (Butterworth, $3^{\text {rd }}$ ed. 1885).

75 'The offensive war is [an act of] international banditry'. Resolutions textuelles des Congres universels de la paix (Berne, 1912). Quoted in Brownlie, International Law and the Use of Force by States 25 (Oxford, Clarendon Press, 1963).

${ }_{77}^{76}$ Brownlie Ian, International Law and the Use of Force by States 42 (Oxford, Clarendon Press, 1963).

${ }^{77}$ The doctrine of self-defense was supposedly developed on the basis of the Caroline -Case, where it was established that self-defense was justifiable if there was a 'necessity, present and inevitable, for attacking'. See Harris D.J., Cases and Materials on International Law 895 (London, Sweet \& Maxwell, 1998).

${ }^{78}$ Brownlie, supra 26 and 28 ff. Example, the Japanese invasion of Chinese Manchuria in 1931 was called an 'incident' in order to avoid the conventional ban on 'war'. See B.V.A. Roling, The Use of Force by States in The Current Legal Regulation of the Use of Force 4 (A. Cassese ed. 1986).
} 
of London, which formally authorized the intervention, stated that it was undertaken 'by sentiments of humanity' ${ }^{79}$

Another example worthy of mention is the French invasion of Syria under the Ottoman Empire in 1860, to rescue severely persecuted Christians. The invasion was sanctioned by some leading European states at the Conference of Paris in the same year. ${ }^{80}$ Though the French troops stayed on and later became 'an occupational force', this instance is widely accepted as a case of humanitarian intervention. $^{81}$

Similarly, Russia intervened in Bosnia, Herzegovina and Bulgaria in 1877, which was also under the rule of the Ottoman Empire. The treatment meted out to Christians in these areas was so cruel that one British investigator described it as 'the most heinous crimes that had stained the history of the century' ${ }^{82}$ The intervention was allegedly carried out on humanitarian grounds.

The invasion of Cuba by the United States in 1898 has also been cited as a case of humanitarian intervention. ${ }^{83}$ In an address to the US Congress, President McKinley said that the purpose of the intervention was 'in the name of humanity and to put an end to the barbarities, bloodshed, starvation and horrible miseries now existing there' ${ }^{84}$

Some leading scholars and writers on international law have doubted the 'genuineness' of these interventions. These scholars, led by Brownlie, argue that these interventions were not

\footnotetext{
${ }^{79}$ The London Treaty for the Pacification of Greece was signed in 1827. See: Abiew, The Evolution of the Doctrine and Practice of Humanitarian Intervention 48-9 (Hague, Kluwer Law International, 1992).

${ }^{80}$ Abiew, The Evolution of the Doctrine and Practice of Humanitarian Intervention 50 (Hague, Kluwer Law International, 1992).

${ }^{81}$ Id. 51. See also Brownlie, International Law and the Use of Force by States 430 (Oxford, Clarendon Press, 1963).

${ }^{82}$ Abiew, The Evolution of the Doctrine and Practice of Humanitarian Intervention 51 (Hague, Kluwer Law International, 1992).

${ }^{83}$ Brownlie, International Law and the Use of Force by States 430 (Oxford, Clarendon Press, 1963). See also M. Walzer, Just and Unjust Wars 104 (New York, Basic Books, $2^{\text {nd }}$ ed. 1992).

${ }^{84}$ Quoted in Abiew, The Evolution of the Doctrine and Practice of Humanitarian Intervention 54 (Hague, Kluwer Law International, 1992).
} 
carried out solely on humanitarian grounds but that power politics between Western and European states also played a role. Subsequently, there has been no clear case of humanitarian intervention. ${ }^{85}$ With regards to the Ottoman Empire, Fenwick states that the 'alleged humanitarian motives were... influenced or affected by the political interests of the intervening state'. ${ }^{86}$ It is also argued that some of the interventions, like those in Syria and Greece were treaty based and not carried out unilaterally. ${ }^{87}$

Nevertheless, the language used by the intervening states clearly indicates some sort of 'opinio juris’ regarding the right of humanitarian intervention. Even if other considerations were also involved the states were arguably "attaching primacy to that principle [of humanitarian intervention] over their treaty rights as the justification for intervention.” ${ }^{\text {„8 }}$ The states themselves were clear in their conviction that humanitarian intervention was a lawful measure of 'lesser armed force’ derived from customary international law.

Again, the argument that treaties authorized the interventions does not detract from the fact that the states involved believed that they were entitled by customary law to intervene for humanitarian purposes because these treaties were not universally adopted. They could hardly therefore create a right to unilateral intervention imposable against the target state.

In the early $20^{\text {th }}$ century, the desire to intervene for humanitarian purposes subsided and the unilateral use of force was largely considered illegal. The creation of the League of Nations gave institutional guarantees to basic rights and the League was given the power to authorize the collective use of force. The League of Nation's Covenant, signed in 1919, sought to restrain countries from going to wars but did not abolish wars altogether. Article 12 (1) provided thus:

\footnotetext{
${ }^{85}$ Brownlie, International Law and the Use of Force by States 340 (Oxford, Clarendon Press, 1963). See also Verwey, Humanitarian Intervention under International Law 32 Neth. I. L. R. 357, 399 (1985).

${ }^{86}$ C.G. Fenwick, Intervention: Individual and Collective 39 Am. J. Int’l L. 645, 650 (1945).

${ }^{87}$ See Brownlie, International Law and the Use of Force by States 430 (Oxford, Clarendon Press, 1963).

${ }^{88}$ Sornarajah, International Colonialism and Humanitarian Intervention, 11 Ga. J. Int'l \& Comp. L. 45, 57 (1981).
} 
The members of the League agree that, if there should arise between them any dispute likely to lead to a rupture, they will submit the matter either to arbitration or judicial settlement or to inquiry by the Council, and they agree in no case to resort to war until three months after the award by the arbitrators or the judicial decision, or the report by the Council. ${ }^{89}$

The attempts in the 1920's to transform the Covenant's partial prohibition of war to a total ban of war culminated in the General Treaty for the Renunciation of War (Kellogg-Briand Pact or the Pact of Paris) which was signed in 1928, which declared in article 1 that: "The High Contracting Parties solemnly declare in the names of their respective peoples that they condemn recourse to war for the solution of international controversies, and renounce it as an instrument of national policy in their relations with one another”. 90

The League and the Kellog-Briand Pact, however, could not prevent wars as totalitarian aggression by Germany and Italy in the early 1930’s led to World War II.

\section{E. CONCLUSION - STATUSQUO OF UNILATERAL HUMANITARIAN INTERVENTION}

\section{BEFORE THE INCEPTION OF THE UNITED NATIONS}

The discussion above suggests that state sovereignty has co-existed with the principle of unilateral humanitarian intervention since the inception of the state system. ${ }^{91}$ A learned author, in 1955, wrote as follows:

[T]here is a substantial body of opinion and practice in support of the view that there are limits to that discretion and that when a State renders itself guilty of cruelties against and persecution of its nationals in such a way as t deny their fundamental human rights and to shock the conscience of mankind, intervention in the interest of humanity is legally permissible. $^{92}$

\footnotetext{
${ }^{89}$ Peter Malanczuk, Akehurst's Modern Introduction to International Law, quoted in Dunoff et al, International Law: Norms, Actors, Process; A Problem Oriented Approach 828 (2002).

${ }^{90}$ General Treaty for the Renunciation of War (1928 emphasis added). The Treaty entered into force immediately, as it was signed by 63 states, an overwhelming number of states at that time. Though the Treaty has not been terminated, it has for all practical purposes been replaced by article 2(4) of the UN Charter.

${ }^{91}$ Abiew, The Evolution of the Doctrine and Practice of Humanitarian Intervention 58 (Hague, Kluwer Law International, 1992).

${ }^{92}$ L.F.L. Oppenheim, International Law- A Treatise 312 (8th ed. by H. Lauterpacht), (London, Longmans, Green \& Co., 1955).
} 
However, a minority of writers dismissed the existence of such a customary right. The issue then turns on interpretation of the available state practice, which is perhaps influenced by a writer's conviction as to whether humanitarian intervention should be lawful or not.

I submit however that in my view the correct position is that unilateral humanitarian intervention was legal under customary law prior to the establishment of the UN. This view is aptly supported by Fonteyne, namely that: "While divergences certainly existed as to the circumstances in which resort could be had to the institution of humanitarian intervention ...the principle itself was widely, if not unanimously, accepted as an integral part of customary international law."93

It is therefore arguable that the customary right of unilateral humanitarian intervention existed as of the time of World War II.

\footnotetext{
${ }^{93}$ J. P. L. Fonteyne, The Customary International Law Doctrine of Humanitarian Intervention, 4 Cal. W. Int’l L. J.
} 203, 234 (1974). 


\section{CHAPTER 3}

\section{TREATY LAW - UNITED NATIONS CHARTER}

The basic regime in international law governing the use of force is that established under the United Nations Charter (UN Charter). The starting point on any discussion about the legality or otherwise of the use of force in international law is article 2(4) of the UN Charter. Article 2(4) provides: “All Members shall refrain in their international relations from the threat or use of force against the territorial integrity or political independence of any state, or in any other manner inconsistent with the objectives of Purposes of the United Nations."

There are only two express exceptions to the rule stated above in the UN Charter. The first is that stated by article 51 of the UN Charter that provides the right of states to use force in self-defense to an armed attack. ${ }^{95}$ Chapter VII of the Charter also provides one express exception to the non-intervention principle by granting powers to the Security Council to use force against any member state if the Security Council believes other measures, not involving the use of force, is not or would not be adequate in the maintenance or restoration of international peace and security. $^{96}$

The ban on the use of force in article 2(4) is complemented by article 2(7) of the Charter that prohibits the United Nations itself from intervening in matters that are essentially within the domestic jurisdiction of any state. ${ }^{97}$ The central issue in this comment is whether in the light of

\footnotetext{
${ }^{94}$ U. N. Charter, art. 2(4).

${ }^{95}$ Article 51 provides:

Nothing in the present Charter shall impair the inherent right of individual or collective self-defense if an armed attack occurs against a member of the United Nations, until the Security Council has taken measures necessary to maintain international peace and security...

${ }^{96}$ U. N. Charter, art. 42.

${ }^{97}$ U. N. Charter, art. 2(7).
} 
articles 2(4) and 2(7) of the UN Charter, there exists the right of humanitarian intervention under the Charter regime itself, looking at the language used in the articles listed above.

Collective intervention authorized by the UN Security Council under Chapter VII of the Charter is obviously valid and is not one of the issues being examined in this comment. The issue is whether individual or collective humanitarian intervention that is not authorized by the Security Council is legal under the Charter.

The Charter itself highlights the tension between the sovereignty, independence, and equality of individual states, on one hand, and the need collectively by the international community to ensure peace and security on the other. ${ }^{98}$

The majority of international law scholars are of the view that humanitarian intervention is not legal under the U. N. Charter. ${ }^{99}$ These scholars argue basically that article 2(4) cannot be interpreted in any way that will allow humanitarian intervention and that as the provisions of the Charter stands now; humanitarian intervention is illegal. Others even go to the extent of holding that the principle of non-intervention has raised to the status of ius cogens - a peremptory norm of general application for which no derogation is permitted. ${ }^{100}$ Other scholars, albeit in the minority, but admittedly of a growing number argue to the contrary, holding that humanitarian

\footnotetext{
${ }^{98}$ http://www.iciss.ca/menu-en.asp

${ }_{99}$ Writers who are generally opposed to the doctrine of humanitarian intervention include Brownlie, "Humanitarian Intervention," in Law and Civil War in the Modern World 217, Fairley, "State Actors, Humanitarian Intervention and International Law: Reopening Pandora's Box,” 10 Ga. J. Int'l \& Comp. L. 29 (1980), Tom Farer, "The Regulation of Foreign Intervention in Civil Armed Conflict," 142 R. C. A. D. I. 291 (1974), Franck \& Rodley, "After Bangladesh: The Law of Humanitarian Intervention by Military Force,"67 Am. J. Int'l. L. 275 (1973), Verwey, “Humanitarian Intervention under International Law," 33 Neth. Int’l L. Rev. 357 (1985) and several more.

${ }^{100}$ Shen Jianming, The Non-Intervention Principle and Humanitarian Interventions Under International Law, 7 Int'l Legal Theory 1(2001).
} 
intervention is legal under the Charter as one of the primary purposes of the Charter is the promotion of human rights. ${ }^{101}$

\section{TEXTUAL ARGUMENTS}

\section{A. CLASSICISTS GOOD FAITH VIEW}

Classicists believe there is no persuasive ground for claiming that a right of humanitarian intervention exists under the UN Charter. First, they assert that there are only two exceptions to the norm prohibiting the use of force in international relations as established by the Charter, namely, that of an assertion of self defense or collective self defense and a Security Council authorization. ${ }^{102}$ The provisions of article 2 (4) read together with article 2 (7), combined with General Assembly resolution $2131^{103}$ totally abolishes the threat or use of force in international relations except with regards to the two exceptions noted above. Therefore, classicists conclude that the Charter prohibits the use of force for humanitarian purposes.

Second, the classicists note that the framers of the U.N. Charter expressly and explicitly provided for two exceptions to the general prohibition on the use of force. ${ }^{104}$ The first exception permits the use of force in self-defense against armed attack ${ }^{105}$ whilst the second permits an action by the Security Council as an enforcement measure in the performance of its duty of maintaining or restoring world peace. ${ }^{106}$ Gordon argues in support of the above assertion that if the framers of the Charter wanted to permit the use of force for humanitarian purposes as a third

\footnotetext{
101 Writers favoring humanitarian intervention include John Rawls, “The Law of Peoples,” 1993, Reisman, “Humanitarian Intervention and Fledgling Democracies,” 18 Fordham Int'l L. J. 794 (1995), D’Amato, “The Invasion of Panama Was a Lawful Response to Tyranny,” 84 Am. J. Int'l L. 516 (1990)

${ }^{102}$ Michael Akehurst, Humanitarian Intervention, in intervention in World Politics 95 (Hedley Bull ed., 1984).

${ }^{103}$ G.A. Res. 2131, 20 U.N. GAOR, 20th Sess., Supp. No. 14, at 11, U.N. Doc A/6014 (1965).

${ }^{104}$ Steve G. Simon, The Contemporary Legality of Unilateral Humanitarian Intervention, 24 Cal. W. Int'l L.J. 117, 128 (1993).

${ }^{105}$ U. N. Charter, art. 51.

${ }^{106}$ U. N. Charter, art. 42. See also Oscar Schacter, International Law: The Right of States to Use Armed Force, 82 Mich. L. Rev. 1620, 1620 (1984).
} 
exception to the prohibition on use of force, they would have done so expressly. ${ }^{107}$ However, the term "humanitarian intervention" cannot be found anywhere in the text of the Charter, indicating clearly that there is no right to use force for humanitarian purposes. ${ }^{108}$

Third, classicists argue against the use of force for humanitarian reasons by relying on two General Assembly resolutions. The first is General Assembly resolution 2625 (U. N. G.A. Res. 2625 (XXV) on the Declaration of Principles of International Law Concerning Friendly Relations and Cooperation Among States in Accordance with the Charter provides that "No state or group of states has the right to intervene, directly or indirectly, for any reason whatever, in the internal or external affairs of another state.” 109

Second, they rely on a 1974 resolution of the General Assembly. The General Assembly defined "aggression" as "the use of armed force by a State against the sovereignty, territorial integrity or political independence of another state..." stated categorically "no justification of whatever nature, whether political, economic, military or otherwise, may serve as a justification for aggression."110 Scholars who are not in favor of the legality of humanitarian intervention argue that the 1970 resolution of the General Assembly of the United Nations was an affirmation of the sacredness of the principle of non-intervention and its primacy in international relations. ${ }^{111}$

Fourth, classicists base their argument against the right to use force for humanitarian purposes on the provisions of the Charter with regard to the use of force in self-defense. Classicists claim that the founders of the Charter were so fearful and skeptical about the

\footnotetext{
${ }^{107}$ Edward Gordon, Article 2 (4) in Historical Context, 10 Yale J. Int'l L. 270, 275 (1985). ${ }^{108} \mathrm{Id}$.

${ }^{109}$ G. A. Res. 2625, U. N. GAOR, 25th Sess., Supp. No. 28, at 121, U. N. Doc. A/8028 (1970).

${ }^{110}$ G. A. Res. 3314, U. N. GAOR, 29th Sess., Supp. No. 31 at 142, U. N. Doc. A/963 (1974).

${ }^{111}$ See for example: T. Modibo Ocran, The Doctrine of Humanitarian Intervention in Light of Robust Peacekeeping, 25 B.C. Int'l \& Comp. L. Rev.1, 14-15 (2002).
} 
unilateral use of force that they even limited the right to self-defense. ${ }^{112}$ This claim is premised on the fact that if an action is taken in self-defense, the state must inform the Security Council immediately. ${ }^{113}$ Once the Security Council takes measures with respect to that attack, the right of self-defense becomes extinguished. ${ }^{114}$ It follows that the right to use force is severely circumscribed if it is limited even in cases of self-defense, which is accepted as a very legitimate case for the use of force. Therefore, it is prudent to prohibit any use of force that is not expressly provided for by the Charter.

Finally, classicists argue that the drafters of the Charter clearly intended the phrase "against the territorial integrity or political independence of any state" to buttress, rather than restrict, the ban on the use of force in international relations." ${ }^{\text {115 }}$ Therefore, humanitarian intervention is clearly illegal under the Charter regime.

\section{B. PROPONENTS (REALISTS) GOOD FAITH VIEW}

Realists on the other hand argue that the inception of the United Nations neither extinguished nor undermined the customary law rule of humanitarian intervention. Rather, the Charter extended and emphasized on the right of humanitarian intervention. ${ }^{116}$

Realists find support for their position with articles of the Charter, which scholars on the other side of the divide rely on. First, they argue that the prohibition of the use of force in Article

\footnotetext{
${ }^{112}$ Steve G. Simon, The Contemporary Legality of Unilateral Humanitarian Intervention, 24 Cal. W. Int'l L.J. 117, 128 (1993).

${ }^{113}$ U. N. Charter, art. 51.

${ }^{114}$ Id.

${ }^{115}$ Brownlie, International Law and the Use of Force, 267 (1963). See also Rosalyn Higgins, The development of International Law through the Political Organs of the United Nations 183 (Oxford University Press, Oxford, 1963).

116 See generally Fernando Teson, Humanitarian Intervention ( $2^{\text {nd }}$ ed. 1997), Michael Reisman \& Myres S. McDougal, Humanitarian Intervention to protect the Ibos, in Humanitarian Intervention and the United Nations 167 (Richard B. Lillich ed.).
} 
2(4) of the UN Charter is not total in the sense that "it forbids only the use of force when it is directed against the territorial integrity or political independence of any state.»117

According to D’Amato, Territorial Integrity means, “preventing the permanent loss of a portion of one’s territory”. ${ }^{118}$ Humanitarian intervention 'properly' so called will not even result in a loss of a nations sovereignty, albeit temporarily. ${ }^{119}$ Again, the concept of political independence means a state's independence must not be compromised. ${ }^{120}$ It is submitted that humanitarian interventions will not have any effect on a nation's independence, and therefore does not violates a nation’s political independence. ${ }^{121}$

Teson, a strong advocate of the legality of humanitarian intervention, sums up the above views regarding the effect of humanitarian intervention on the political independence and territorial integrity of the target state. He stated that the use of force is prohibited: (a) when it impairs the territorial integrity of the target state; (b) when it affects its political independence; or (c) when it is otherwise against the purposes of the United Nations."122

He argues further that a genuine humanitarian intervention neither impairs the territorial integrity of the target state nor results in political subjugation. ${ }^{123}$ Therefore, in Teson's opinion, a critical look at the ordinary meaning of the words used in article 2(4) and as understood by the drafters of the Charter, tests (a) and (b) of his three-prong tests are satisfied. ${ }^{124}$ The issue then is

\footnotetext{
117 Julius Stone, Aggression and world Order: A Critique of United Nations World Theories of Aggression, 95 (Stevens, London, 1958).

${ }^{118}$ Anthony D’Amato, International Law: Process and Prospect 59 (1987).

119 Steve G. Simon, The Contemporary Legality of Unilateral Humanitarian Intervention, 24 Cal. W. Int'l L. J. 117, 130 (1993).

${ }^{120} \mathrm{Id}$.

${ }^{121} \mathrm{Id}$.

${ }^{122}$ Teson, Humanitarian Intervention, $150\left(2^{\text {nd }}\right.$ ed. 1997).

${ }^{123}$ Id. at 151.

${ }^{124}$ He stated thus: "Since a humanitarian intervention seeks neither a territorial change nor a challenge to the political independence of the State involved and is not only inconsistent with the purposes of the United Nations but is rather in conformity with the most peremptory norm of the Charter, it is a distortion to argue that it is precluded by Article 2(4)".
} 
whether humanitarian intervention will survive the "purpose" test. ${ }^{125}$ Since the promotion of justice and human rights is one of the purposes of the United Nations, then humanitarian intervention is legal under the Charter regime.

Realists also argue that there is no doubt that the promotion of human rights is an important purpose of the United Nations Charter. Article 1(3) of the United Nations Charter states that one of the purposes of the United Nations is to achieve international cooperation...in promoting and encouraging respect for human rights and fundamental freedoms for all without distinction as to race, sex, language, or religion. Teson states that a purposive reading of article 2(4), a reading that is dictated by the wording of the provision itself, indicates that the use of force to overthrow regimes that do not respect fundamental human rights cannot be included in the blanket prohibition of the provision in article 2(4). ${ }^{126}$ He contends further that the use of force to curtail serious human rights violations, far from being "contrary to the purposes" of the United Nations Charter, serves one of its main purposes. ${ }^{127}$

Finally, it follows logically that if all uses of force with the exception of those expressly stated in the Charter were illegal, then the qualifying clauses to article 2 (4) becomes redundant. In other to give effect to the qualifying clauses in article 2 (4) therefore, one has to look at other parts of the Charter. Since the preamble to the Charter lists the promotion of human rights as one of its purposes, then humanitarian intervention is not inconsistent with the Charter. ${ }^{128}$

\footnotetext{
125 Id.

126 Teson, Humanitarian Intervention 151 ( $2^{\text {nd }}$ ed. 1997).

${ }^{127} \mathrm{Id}$.

128 Tom J. Farer, An Inquiry into the Legitimacy of Humanitarian Intervention, in Law and Force in the New International Order 185, 190 (Lori F. Damrosch \& David J. Scheffer eds. 1991).
} 


\section{SUMMARY OF THE TEXTUAL ARGUMENTS}

Though both classicists and realists present credible arguments as to the legality of unilateral humanitarian intervention, the classicist position is generally accepted. ${ }^{129}$ However, it is not very clear whether unilateral humanitarian intervention is permitted under the UN Charter as the wording of Article 2(4) leaves much to be desired. Generally, the mentioning of something means the exclusion of all that is not mentioned. This will support the case of the classicist that the drafters could have specifically provided for humanitarian intervention the same way it provided for self-defense.

However, it is also true that the acceptance of the reasoning above leaves some words in Article 2(4) redundant. Generally, if a provision can be interpreted reasonably without leaving any words redundant, that interpretation is preferable to the interpretation that leaves some words redundant. This obviously supports the case of the realist.

\section{INTENT ARGUMENTS}

\section{A. CLASSICISTS VIEW OF INTENT}

Classicists argue that the most paramount of values sought to be protected under the Charter regime is that of non-intervention, which the framers believed would culminate in world peace. ${ }^{130}$ This desire for peace makes the prohibition on the use of force in international disputes one of the most fundamental goals of the United Nations. ${ }^{131}$ Thus, under the Charter, the use of force is not legitimized simply because it is in the interest of justice. The Charter chose peace over justice in the event of a conflict between these two important goals of the United Nations.

\footnotetext{
${ }^{129}$ Steve G. Simon, The Contemporary Legality of Unilateral Humanitarian Intervention, 24 Cal. W. Int'l L.J. 117, 132 (1993).

${ }^{130}$ Louis Henkin, The Use of Force: Law and U.S. Policy, in Right v. Might 38 (L. Henin et al. eds. 1991).

${ }^{131}$ Edward Gordon, Article 2(4) in Historical Context, 10 Yale J. Int'l L. 270, 275 (1985).
} 
Force is therefore forbidden as a means of enforcing rules of international law or treaties. ${ }^{132}$ Cassese for instance categorically states that "any time that conflict or tension arises between two or more of these values; peace must always constitute the ultimate and prevailing factor”. ${ }^{133}$

Some Classicists also argue that a look at some of the language debated in the formulation of the Charter. For instance, it is said that one of the proposals called for the "protection of human rights," instead of the "promotion of human rights” which was eventually put in the text of the Charter. ${ }^{134}$ It is submitted that the use of the word "protect" would allow for a more rigorous defense of human rights as compared to the relatively meek "promote" which was eventually accepted by the founders of the Charter. ${ }^{135}$

The proposal to use the word "protect" was not accepted because "it would raise hopes beyond what the United Nations could successfully accomplish."136 It is submitted that the use of "promote" meant that the founders of the Charter expressed a right that cannot be enforced by going as far as the use of force. Thus, many ratifying nations recognized the insufficiency of the articles meant to ensure that human rights were upheld and accordingly hoped to pass a Bill of Rights to help enforce the protection of human rights. ${ }^{137}$

\section{B. REALISTS VIEW OF INTENT}

Realists argue forcefully that the human rights provisions in the Charter were not put there accidentally or carelessly but that nations felt the need to ensure that all enjoyed fundamental human rights. In His leading work on the human rights provisions of the Charter, Lauterpacht insists that the human rights provisions were adopted only after an extensive

\footnotetext{
${ }_{132}^{132}$ Oscar Schacter, Just War and Human Rights, 1 Pace Y.B. Int’l L. 1, 4 (1989).

133 Antonio Cassese, "Ex Iniuria Ius Oritur: Are We Moving Towards International Legitimization of Forcible Humanitarian Countermeasures in the World Community?” 10 Eur. J. Int’l L. 23, 24(1999).

${ }^{134}$ H. Lauterpacht, International Law and Human Rights 145-6 (1986).

${ }^{135}$ Steve G. Simon, The Contemporary Legality of Unilateral Humanitarian Intervention, 24 Cal. W. Int'l L.J. 117, 132 (1993).

${ }^{136} \mathrm{Id}$.

${ }^{137} \mathrm{Id}$.
} 
discussion, making it a legal duty for nations to respect and observe. ${ }^{138}$ He recognized that the Charter drafters could have used a much stronger word such as "respect" instead of "promote" but insisted that such an omission was of little practical importance:

[I]t would be out of keeping with the spirit of the Charter and, probably with the accepted canons of interpretation of treaties, to attach decisive importance to that omission (of the word "respect"). It would be otiose to the point of pedantry for the draftsmen of the Charter to incorporate an explicit provision of this nature in a document in which the principle of respect for and observance of human rights... is one of the main pillars of the structure of the Organization... ${ }^{139}$

Adding to the strength of the above argument is the fact that the original proposal of the U.N., prepared by the great powers after World War II contained just one general provision with respect to human rights. However, non-governmental organizations and the smaller states were determined and ensured that the ratified version contained substantial provisions on human rights. ${ }^{140}$ Logically, it took a lot of efforts and emphasis in getting these human rights provisions included in the ratified version considering the fact that the great powers did not consider it very important initially.

Again, it is only logical to conclude that human rights violations are matters of international concern and not solely matters of domestic concern. ${ }^{141}$ Concluding that human rights are solely matters of domestic concern would nullify many international agreements by rendering them ultra vires. If the argument that human rights are only matters of domestic concern were upheld, then every government would be guilty of interfering in the domestic affairs of another nation. This is predicated on the premise that nearly all nations are now subject to some international human rights agreement which obliges them to promote and protect the

\footnotetext{
${ }^{138}$ Sir H. Lauterpacht, International Law and Human Rights 147 (1968).

${ }^{139}$ Id.

${ }^{140}$ A. H. Robertson \& J.G. Merrills, Human Rights in the World 24 (1989).

${ }^{141}$ Various resolutions of the Security Council of the UN has, in fact declared human rights violations to be a matter of international concern and not within the domestic jurisdiction of a state. See, e.g., U.N. Security Council Resolution No. 216 at U.N. Doc. A/RES/216 (1965); U.N. Security Council Resolution No. 217 at U.N. Doc. A/RES/217 (1965); U.N. Security Council Resolution No. 232 at U.N. Doc. A/RES/253 (1968).
} 
human rights of their inhabitants. Efforts to ensure compliance with their treaty obligations cannot be said to be improper interference in domestic affairs. ${ }^{142}$

Again, pro-interventionists argue that there is a necessary link between the maintenance of peace and respect for human rights. ${ }^{143}$ Human rights would be of international concern as soon as it was foreseeable that they presented a threat to the peace. ${ }^{144}$ The UN Charter provides the Security Council the authority to intervene when the peace is breached, ${ }^{145}$ it is argued that serious human rights abuses and deprivations, should give rise to an analogous permission. This assumption may provide another reason to intervene in cases where human rights deprivations have or is threatened to result in a breach of international peace. ${ }^{146}$ Humanitarian intervention is therefore not inconsistent with the provisions of the UN Charter.

\section{SUMMARY OF THE INTENT ARGUMENTS}

The intent arguments posited by both realist and classicist are tenable. It is abundantly clear that the drafters of the UN Charter intended to halt both aggression and violations of human rights. ${ }^{147}$ It is however not clear whether they intended to sacrifice one value for the other in case of conflict. As D’Amato has observed, it is very difficult to determine the intent of a large group of people as the framers of the UN Charter. ${ }^{148}$

What makes classicists intent arguments an intriguing one is the fact that a prohibition on unilateral use of force for human rights amounts to a tacit acceptance of the non-existence of human rights. This flows from the fact that denying force to curtail human rights violations when

\footnotetext{
${ }^{142}$ Steve G. Simon, The Contemporary Legality of Unilateral Humanitarian Intervention, 24 Cal. W. Int'l L.J. 117, 134 (1993).

${ }^{143}$ See McDougal \& Reisman, "Rhodesia and the United Nations: The Lawfulness of International Concern," 62 Am. J. Int'l. L. 1, 15 (1968).

${ }^{144}$ Teson, Humanitarian Intervention, $152\left(2^{\text {nd }}\right.$ ed. 1997).

${ }^{145}$ See U.N. Charter, Chapter VII.

${ }^{146}$ See for example Security Council Resolution 134 of 1960.

${ }^{147}$ Steve G. Simon, The Contemporary Legality of Unilateral Humanitarian Intervention, 24 Cal. W. Int'l L.J. 117, 136 (1993).

${ }^{148}$ Anthony D’Amato, International Law: Process and Prospect 72-3 (1986).
} 
all other methods have proved futile only means those human rights are devoid of remedy. But as rightly pointed out by Franck and Rodley, a right without a remedy logically implies the nonexistence of that the right. ${ }^{149}$

\section{POLICY ARGUMENTS}

To the extent the legality of unilateral humanitarian intervention is not clear from the provisions of the UN Charter, both realist and classicist often tend to rely on policy reasons to support their respective claims. The realists contend that the inability of the SC to perform its role effectively allows states to retain a residual right to intervene unilaterally when the need arises. The classicists on the other hand rely on the possibility of abuse if unilateral humanitarian intervention is permitted.

\section{A. CLASSICISTS ‘ABUSE’ ARGUMENT AND REALISTS RESPONSE}

Classicists argue that in any human endeavor there is the possibility of abuse and therefore it will be too dangerous to allow a right of humanitarian intervention. ${ }^{150}$ The possibility of abuse was highlighted by the ICJ when it observed that an "alleged right of intervention as the manifestation of a policy of force, such as has, in the past, given rise to most serious abuses and as such cannot ... find a place in international law. ${ }^{151}$

Classicists contend that humanitarian intervention is just a way of allowing the strong to intervene in weaker states to promote their own agenda since it is unrealistic to imagine that potential interveners would disregard any advantages they may gain and act solely for humanitarian reasons. ${ }^{152}$

\footnotetext{
149 Thomas M. Franck \& Nigel S. Rodley, After Bangladesh: The Law of Humanitarian Intervention by Military Force, 67 Am. J. Int'l L. 275, 299 (1973).

${ }^{150}$ See generally, Edward Gordon, Article 2 (4) in Historical Context, 10 Yale J. Int’l L. (1985).

${ }^{151}$ Corfu Channel Case (UK v. Albania), 1949 ICJ Rep. 4 (Judgment of Apr. 9).

152 Farooq Hassan, Realpolitik In International Law: After Tanzanian-Ugandan Conflict "Humanitarian Intervention” Reexamined, 17 Williamette L. Rev. 859, 881 (1981).
} 
Realists have responded to the possibility of abuse with two strong counter- arguments. First, they assert that the UN must deal with the underlying problem and not eradicate the problem. An accurate analogy is offered using police officers and crime in the United States. The fact that the police had on occasion abused their powers while trying to prevent crime does not mean the United States government should eliminate the police. Therefore, the best way out is to eliminate the problem of human rights violations and not humanitarian intervention. ${ }^{153}$

Second, the absolute prohibition of unilateral humanitarian intervention is premised on the argument that the utility that will be derived from prohibition of the rule will be better than the utility to be gained if the rule is allowed. However, this will not always be true as in some circumstance; it will be obvious that allowing for humanitarian intervention would be better than denying it. ${ }^{154}$

\section{B. REALISTS ‘FAILURE OF THE UN’ ARGUMENT AND CLASSICISTS RESPONSE}

Realists argue that even if the UN Charter sought to prohibit the unilateral use of force for humanitarian purposes, states retain a residual right because of the ineffectiveness of the Security Council to act in the face of gross violations of human rights. Jessup contends that "[i]t would seem that the only possible measures under the Security Council for individual measures by a single state would be the inability of the international organization to act with the speed requisite to preserve life". ${ }^{155}$

Realists acknowledge that the right to use force unilaterally is retained by states only because the UN system has failed to function the way it was set up to. A proper functioning of the world body would obviate any need for the unilateral use of force. ${ }^{156}$ However, the Charter

\footnotetext{
153 A. H. Robertson \& J. G. Merrils, Human Rights in the World 1 (1989).

154 Teson, Humanitarian Intervention: An Inquiry into Law and Morality 103 (1988).

155 P. Jessup, A Modern Law of Nations 170-71 (1948).

${ }^{156}$ Michael Reisman, Criteria for the Lawful Use of Force in International Law, 10 Yale J. Int'l L. 279 (1985).
} 
system never functioned the way the drafters intended it to. During the Cold War, the Security Council was paralyzed as the permanent members of the Security Council frequently used their veto power to ensure that there was never a consensus within that body. ${ }^{157}$

It is submitted that member states of the UN surrendered their customary right to use force for on the condition of creating an effective collective security and enforcement machinery by the UN. Since the UN has failed in its role, especially because of the excessive use of the veto by the permanent members of the Security Council, the executive arm of the UN, members are partially relieved of their obligation not to use force unilaterally. ${ }^{158}$

There are numerous examples of situations where the need for UN action was obviously needed in the face of massive human rights abuses but the UN failed to intervene. Examples include the Indonesian government's killing of hundreds of political nonconformists in the mid1960's, the Rwandan genocide which witnessed the slaughter of hundreds of thousands Tutsis, the decimation of thousands of Hutus in Burundi, the Southern Sudanese government's massacre of secessionist blacks and the killing of almost one million Ibos at the hands of the Nigerian government. $^{159}$

In the face of no assistance from the UN when atrocities are going on, realists contend that it is in the best interest of the world for society to retain some measure of unilateral use of force.

\footnotetext{
${ }^{157}$ Peter Malanczuk, Akehurst's Modern Introduction to International Law, quoted in Dunoff et al, International Law: Norms, Actors, Process; A Problem Oriented Approach 827 (2002).

${ }^{158}$ Jean-Pierre L. Fonteyne, The Customary International Law Doctrine of Humanitarian Intervention, 4 Cal. W. Int'l L.J. 203, 257 (1974).

${ }^{159}$ Michael J. Bazyler, Reexamining the Doctrine of Humanitarian Intervention in Light of Atrocities in Kampuchea and Ethiopia, 23 Stan. J. Int'l L. 547, 595-6 (1987).
} 
The fact that the UN system has failed to function the way it was set up is not in dispute. Subsequently, classicists have found it difficult to offer constructive responses to this realists' argument.

\section{CONCLUSION: STATUS OF UNILATERAL HUMANITARIAN INTERVENTION} UNDER THE UN CHARTER.

The legality of unilateral humanitarian under the UN Charter can be ascertained by applying the rules on treaty interpretation as stated in the Vienna Convention on the Law of Treaties. The basic principle of interpretation of treaties as stated in the Vienna Convention on the Law of Treaties posits that a treaty shall be interpreted in good faith in accordance with the ordinary meaning of the words of the treaty in their context, having regard to the object and purpose of the treaty. ${ }^{160}$ It says that the context for the purpose of interpreting a treaty shall comprise the text of the treaty, its preamble and annexes. ${ }^{161}$

A careful reading of article 2(4), giving the words their ordinary meaning in their context and in the light of its object and purposes does not resolve the impasse. A look at the context of the UN Charter does not help in the determination of the legality of humanitarian intervention under the Charter. As stated earlier, both views on the interpretation of Article 2(4) are tenable. $^{162}$

An inquiry into the UN Charter's preamble, an important part of the context of the treaty, provides no answer as to the legality or otherwise of humanitarian intervention under the Charter regime. The preamble states among other things the determination on the part of the members to "save succeeding generations from the scourge of war." However, it urges states to put into place

\footnotetext{
${ }^{160}$ Vienna Convention on the Law of Treaties, art. 31(1) (1969).

${ }^{161}$ See the full text of article 31 of the Vienna Convention on the Law of Treaties for a list of all the materials that must be taken into consideration in treaty interpretation.

${ }^{162}$ See Stone, Aggression and World Order 97 (1958) where he concurs with the view that both interpretations of Article 2 (4) are tenable.
} 
a system under which "justice" can be maintained. ${ }^{163}$ This may include using force to overthrow regimes that persistently deny fundamental human rights to their own citizens. Thus, the two dictates of the preamble as listed above are in direct conflict with each other, one supporting the legality of humanitarian intervention and the other not. The object and purpose of the UN Charter is of little help as the competing values, peace and justice are both part of the purposes of the UN. ${ }^{164}$

According to the Vienna Convention on the Law of Treaties, where the ordinary meaning of a provision in a treaty is ambiguous, recourse may be had to the supplementary means of interpretation. ${ }^{165}$ It states that the supplementary means of interpretation includes the preparatory work of the treaty (travaux preparatoires) and the circumstances of its conclusion. ${ }^{166}$

The travaux preparatoires of the Charter itself does not help much in the determination of the true meaning of Article 2 (4) of the Charter, as there is little documentary evidence of the content of the travaux preparatoires of the Charter. Scholastic opinion is also not unanimous on the issue; whilst some contend that the travaux preparatoires is of little assistance in the search of the meaning of Article 2(4), others have contrasting accounts of the content of the travaux preparatoires.

According to Brownlie, an examination of the travaux preparatoires does not indicate whether the framers intended to maintain the customary exceptions to the use of force, including humanitarian intervention. ${ }^{167}$ Professor Lillich however observed that Brownlie’s own account is not supportive of his conclusion that the final clause of Article 2(4) does not qualify the

\footnotetext{
${ }^{163}$ See Preamble to U.N. Charter.

${ }^{164}$ See U. N. Charter, art. 1.

${ }^{165}$ Article 32 of the Vienna Convention on the Law of Treaties ${ }^{166}$ Id.

${ }^{167}$ See Brownlie, International Law and the Use of Force by States 264-8 (1963). See also Jean-Pierre L. Fonteyne, The Customary International Law Doctrine of Humanitarian Intervention, 4 Cal. W. Int'l L.J. 203, 242-6 (1974).
} 
prohibition. ${ }^{168}$ It is posited that a Norwegian suggestion to omit the qualifying clause in Article 2(4) was declined in San Francisco. ${ }^{169}$

Despite the difficulty in accessing the legality of humanitarian intervention under the UN Charter, it is the view of the present author that humanitarian intervention is not permissible under the Charter regime. The arguments by the classicists are more persuasive legally although as a policy matter, the arguments put forward by the realists are more appealing.

A look at other legal instruments signed in the years immediately preceding the signing of the UN Charter leaves me in no doubt that the use of force was generally prohibited at the time. For instance, the Pact of the Arab League provided that "recourse to force for the settlement of disputes arising between two or more member states of the League is prohibited”. ${ }^{170}$ Similarly, it is significant to note that the Charter of the Organization of American States (Bogotá Charter) signed just one year after the Janeiro Treaty contained certain provisions that extensively prohibited the use of force in international relations. ${ }^{171}$ Almost all of these treaties made specific reference to the UN Charter.

A considerable number of agreements, in addition to the ones stated above, essentially prohibited the use of force in international relations. ${ }^{172}$ A critical appraisal of the arguments of both classicists and realists, considered together with all the treaties that were entered into in the years immediately preceding the coming into force of the UN Charter, indicate that the UN Charter essentially sought to prohibit the unilateral use of force save in the circumstances expressly stated.

\footnotetext{
${ }^{168}$ Lillich, "Humanitarian Intervention: A Reply to Ian Brownlie and a Plea for Constructive Alternatives,” in Law and Civil War in the Modern World 229 (J. N. Moore ed., 1974).

169 See Teson, Humanitarian Intervention 154 ( $2^{\text {nd }}$ ed. 1997).

${ }^{170}$ Brownlie, International Law and the Use of Force by States 116 (1963).

${ }^{171}$ Id. at 117.

${ }^{172}$ Examples include the Act of Chapultepec of March 3, 1945, the Inter-American Treaty of Reciprocal Assistance (Janeiro Treaty) signed at Rio de Janeiro of September 2, 1947 and the Final Communiqué of the Afro-Asian Conference at Bandung, of April 24, 1955. See Brownlie Id. 116-120 for a thorough discussion of these treaties.
} 


\section{CHAPTER 4}

\section{CUSTOMARY INTERNATIONAL LAW}

\section{DEFINITION}

Customs in international law can generally be defined as rules developed by the practice of states, which rules the states concerned follow because they believe there is a rule of law requiring them to behave as such. Rebecca Wallace defines it as “... a practice followed by those concerned because they feel legally obliged to behave in such a way”. ${ }^{173}$ Thus, for there to exist a rule of customary international law, there must be a practice that is followed by the generality of states in the belief that there is a rule of law requiring such practice.

It is important to distinguish custom from other rules that states may follow not out of any feeling of a legal obligation, such as behavior undertaken out of courtesy, friendship or convenience. The difference between customs and these other norms is the fact that custom is derived from two elements: (i) a material element (state practice) and (ii) a psychological element (opinio juris). ${ }^{174}$ The material element is derived from the practice and behavior of states whereas the psychological element is the subjective conviction held by states that the behavior is question is necessitated by a rule of law and not discretionary. ${ }^{175}$

\section{ELEMENTS OF CUSTOM}

As indicated above, the two elements of customary rules of international law are state practice and opinio juris.

\footnotetext{
${ }^{173}$ Rebecca M.M. Wallace, International Law, 9 ( $3^{\text {rd }}$ ed. 1997).

${ }^{174} \mathrm{Id}$.

${ }^{175} \mathrm{Id}$
} 


\section{A. STATE PRACTICE AND ITS CONSTITUENT ELEMENTS}

It is essential to determine what constitute state practice as it has been referred to appropriately as the raw material of customary law. ${ }^{176}$ In the ascertainment of state practice, we have to look at "what states do in their relations with one another"177 or as stated by Professor McDougal, the "process of continuous interaction, of continuous demand and response". ${ }^{178}$ State practice therefore includes any act, articulation or other behavior of a state that discloses the state's conscious attitude with respect to its recognition of a rule of customary international law. $^{179}$

The International Law Commission in 1950 listed the following as forms of "Evidence of Customary International Law”: [T]reaties, decisions of national and international courts, national legislation, diplomatic correspondence, opinions of national legal advisers, practice of international organizations. ${ }^{180}$

Thus, state practice may include diplomatic correspondence, general declarations of foreign or legal policy ${ }^{181}$, opinion of national legal advisers in domestic and international fora. Judge Ammoun in his separate opinion in the Barcelona Traction, Light and Power Company Case $^{182}$ considered the importance of such statements when he stated that, with respect: "to return to State practice as manifested within international organisations and conferences, it cannot denied, with regard to the resolutions which emerge therefrom, or better, with regard to

\footnotetext{
${ }^{176}$ Mark E. Villiger, Customary International Law and Treaties, 4 (1985).

${ }^{177} \mathrm{Id}$.

${ }^{178} \mathrm{Id}$.

${ }^{179} \mathrm{Id}$.

${ }^{180}$ See Yearbook of the International Law Commission II $368 \mathrm{ff}$. (1950).

${ }^{181}$ See the Nuclear Tests Case (Australia v. France), ICJ Rep.266 ff. (1974) where the ICJ regarded as significant a press statement of the French government that it would cease to undertake atmospheric tests.

${ }^{182}$ ICJ Rep. 3 (1970). (Second Phase).
} 
the votes expressed therein in the name of States, that these amount to precedents contributing to the formation of custom”. ${ }^{183}$

Despite the acceptance of these indicators of state practice, the importance of overt state practice in the formation of custom should not be discounted. ${ }^{184}$ This was emphasized by the ICJ in the Continental Shelf Case (Libya v. Malta) ${ }^{185}$ when the Court stated: "It is of course axiomatic that the material of customary international law is to be looked for primarily in the actual practice and opinio juris of states even though multilateral conventions may have an important role to play in defining and recording rules, deriving from custom or indeed in developing them". 186

State practice can be determined from the extent of a particular practice as well as the duration of the practice.

\section{Extent of Practice}

It is essential for the formation and existence of a customary rule that there exists general State practice. Article 38 of the ICJ statute itself mentions "general practice". The ICJ held in the Asylum Case $^{187}$ that for state practice to amount to law, it had to be in accordance with a “constant and uniform usage” practiced by the states in question. ${ }^{188}$

Similarly, the ICJ emphasized the importance of an extensive practice by the generality of states in the Fisheries Case (UK v. Norway) when it stated that:

[A]lthough the ten-mile rule has been adopted by certain States both in their national law and in their treaties and conventions, and although certain arbitral decisions have applied it as between these States, other States have adopted a different limit. Consequently, the ten-mile rule has not acquired the authority of a general rule of law. ${ }^{189}$

\footnotetext{
${ }^{183} \mathrm{Id}$.

${ }^{184}$ Rebecca M.M. Wallace, International Law, (3 ${ }^{\text {rd }}$ ed. 1997), 15.

185 ICJ Rep. 13 (1985).

${ }^{186}$ Id. 29-30. See also the view of Anthony D’Amato in The Concept of Custom in International Law 88 (1971).

${ }^{187}$ I.C.J. Rep. 266 (1950).

188 Id. at 277.

${ }^{189}$ ICJ Rep. 131(1951).
} 
The ICJ again gave an insight into the extent of practice needed to form a rule of customary international law in the North Sea Continental Shelf Cases. The Court stated that “..., State practice, including that of states whose interests are specifically affected, should have been both extensive and virtually uniform....”190

The locus classicus of the extent of practice required for the formation of a rule of customary international law can be found in the judgment of the ICJ in the Asylum Case where it stated that:

The party which relies on a custom ... must prove that this custom is established in such a manner that it has become binding on the other party ... that the rule invoked ... is in accordance with a constant and uniform usage practiced by the States in question, and that this usage is the expression of a right appertaining to the State granting asylum and a duty incumbent on the territorial State. This follows from Article 38 of the Statute of the Court, which refers to international custom 'as evidence of a general practice accepted as law'. The facts brought to the knowledge of the Court discloses so much uncertainty and contradiction, so much fluctuation and discrepancy in the exercise of diplomatic asylum and in the official views expressed on different occasions; there has been so much inconsistency in the rapid succession of conventions on asylum, ratified by some States and rejected by others, and the practice has been so much influenced by considerations of political expediency in the various cases, that it is not possible to discern in all of this any constant and uniform usage, accepted as law .... ${ }^{191}$

The above decisions clearly indicate that for the existence of a rule of customary law, there must be an extensive practice by the generality of states. No rule may be accepted as a rule of customary law without meeting the criteria of extensive practice. Whilst it is not essential for there to be universal practice, practice should be representative, ${ }^{192}$ of at least the major political and socio-economic systems. ${ }^{193}$

\footnotetext{
190 ICJ Rep. 43 (1969).

${ }^{191}$ ICJ Rep. (1950), 276-7. See also U.S. Nationals in Morocco Case, ICJ Rep. (1952), 200, Rights of Passage Case (Merits), ICJ Rep. (1960) 40, 43.

192 See the ICJ's views in the North Sea Cases, ICJ Rep. (1969), 42.

193 Professor Rene Dupuy, Sole Arbitrator in the Texaco v. Libya Arbitration, ILR 53 (1979) 487 ff.
} 
However, a single act may lead to the establishment of a rule of customary law if it is accompanied by a widespread support for the action. O'Connell succinctly stated this when she stated that the instances in which one act results in the establishment of a rule of customary rule are rare. She noted "[w]hatever the arguments, international legal rules are not easily changed. One act not in conformity with the rules does not eliminate a legal regime, unless one finds overwhelming support for that change."194

\section{Duration}

Generally, there is no specific time limit that is required for the emergence of a rule of customary law. ${ }^{195}$ Brownlie states that provided the consistency and generality of a practice is established, no particular duration is required. ${ }^{196}$ The passage of only a short time is not itself a bar to the formation of a rule of customary law. ${ }^{197}$ The ICJ emphasized the relative less importance of time if other conditions are satisfied in the formation of custom in the North Sea Continental Shelf Cases ${ }^{198}$ when it stated thus:

... Although the passage of only a short period of time is not necessarily, or of itself, a bar to the formation of a new rule of customary international law ... an indispensable requirement would be that within the period in question, short though it might be, State practice ... should have been both extensive and virtually uniform in the sense of the provision invoked; - and should moreover have occurred in such a way as to show a general recognition that a rule of law or legal obligation is involved. ${ }^{199}$

The length of time required for the formation of a rule of customary international law will therefore depend on other factors pertinent to the alleged rule. ${ }^{200}$

\footnotetext{
${ }^{194}$ Mary Ellen O’Connell, “The UN, NATO, and International Law after Kosovo,” 22 Hum. Rts. Q. 57, 82 (2000).

${ }^{195}$ Rebecca M.M. Wallace, International Law 10 ( $3^{\text {rd }}$ ed. 1997).

${ }^{196}$ Ian Brownlie, Principles of Public International Law, 7 ( $6^{\text {th }}$ ed. 2003).

${ }^{197}$ Rebecca M.M. Wallace, International Law 10 ( $3^{\text {rd }}$ ed. 1997).

${ }^{198}$ ICJ Rep. 3 (1969).

${ }^{199}$ Id. at 43.

${ }^{200}$ Rebecca M.M. Wallace, International Law 10 (3 ${ }^{\text {rd }}$ ed. 1997).
} 


\section{B. OPINIO JURIS SIVE NECESSITATIS (OPINIO JURIS)}

This is the psychological element that draws the distinction between conduct and behavior which states enter undertake because they feel there is a rule of law requiring it and conduct or behavior which may be undertaken by states out of political expediency, courtesy or other reasons. ${ }^{201}$ Hudson posited that the "practice is required by, or consistent with, prevailing international law”. ${ }^{202}$

The practice of the ICJ has revealed that in some cases the Court is willing to assume the existence of an opinio juris based on the availability of state practice, or a consensus in the literature, or the previous determination of the Court or other international tribunals. ${ }^{203}$ In other cases, however, the Court has taken a different approach by calling for a more positive evidence of the existence of opinio juris. ${ }^{204}$

The main problem with opinio juris is one of proof as it is frequently difficult to determine when the transformation has taken place to make a practice a rule of law. ${ }^{205}$ Generally speaking, it is the party alleging the existence of custom that must prove its existence for the other party to be bound by that rule. ${ }^{206}$

A number of decisions of the ICJ brought to the fore the important role of opinio juris in the customary law making process. The first authoritative statement on the requirement of opinio juris in the formation of rules of customary international law was made by the Permanent Court of International Justice (PCIJ), the predecessor of the ICJ in the celebrated case of the S.S.

\footnotetext{
${ }^{201}$ See ICJ Statute, Article 38 (1) (b) where it refers to 'a general practice accepted as law'. See also Rebecca M.M. Wallace, International Law 9 ( $3^{\text {rd }}$ ed. 1997) and Ian Brownlie, Principles of Public International Law, (6 $6^{\text {th }}$ ed. 2003), 8.

${ }^{202}$ The Work of the International Law Commission, 42.

${ }^{203}$ Brownlie, supra.

${ }^{204}$ Id.

${ }^{205}$ Wallace, supra 17.

${ }^{206}$ Id.
} 
Lotus. $^{207}$ In that case, France identified several instances where the flag state of a victim of a collision on the High Seas had failed to institute criminal prosecution against the alleged offender(s). The Court nevertheless failed to find the existence of a rule of customary international law requiring such practice. The Court said:

Even if the rarity of the judicial decisions to be found among the reported cases were sufficient to prove in point of fact the circumstances alleged by the Agent of the French Government, it would merely show that States had often, in practice, abstained from instituting criminal proceedings, and not that they recognized themselves as being obliged to do so; for only if such abstention were based on their being conscious of a duty to abstain would it be possible to speak of an international custom. The alleged fact does not allow one to infer that States have been conscious of having such a duty; on the other hand ... there are other circumstances calculated to show that the contrary is true. ${ }^{208}$

Similarly, the ICJ maintained in the North Sea Continental Shelf Cases that, although the principle of equidistance was employed in the delimitation of the continental shelf cases between adjacent states, there was no evidence to prove that “... they so acted because they felt legally compelled to draw them in this way by reason of a rule of customary international law obliging them to do so - especially considering that they might have been motivated by other factors”. ${ }^{209}$

The ICJ summed up the requirements of customary international law, emphasizing the importance of both state practice and opinio juris in the Case of Nicaragua v. United States (Merits) ${ }^{210}$ where the Court noted as follows:

In considering the instances of the conduct above described, the Court has to emphasize that, as was observed in the North Sea Continental Shelf cases, for a new customary rule to be formed, not only must the acts concerned 'amount to a settled practice', but they must be accompanied by the opinio juris sive necessitates. Either the States taking such action or other States in a position to react to it, must have behaved so that their conduct is 'evidence of a belief that this practice is rendered obligatory by the existence of a rule of law requiring it. The need for such a belief, i.e. the existence of a subjective element, is implicit in the very notion of the opinio juris sive necessitatis'. ${ }^{211}$

\footnotetext{
${ }^{207}$ P.C.I.J. Rep., Ser. A, No. 10 (1927).

${ }^{208}$ P.C.I.J. Rep., Ser. A, No. 10, 28 (1927) (emphasis added).

${ }^{209}$ ICJ Rep. 44-5 (1969).

${ }^{210}$ ICJ Rep. 14 (1986).

${ }^{211}$ Id. 108-9.
} 
Thus, for the formation and existence of rules of customary international law, both the state practice and the opinio juris must exist simultaneously. If this criterion is not met, there can be no rules of customary international law as the decisions of the ICJ have made clear.

\section{STATE PRACTICE AFTER 1945}

\section{Interventions During the Cold War, 1945-1989}

The period after World War II was characterized by distrust and enmity, 'the Cold War', between the Western and the Sino-Soviet countries and their allies. The two sides refused to cooperate on the international arena, and often supported different sides of a conflict merely in defiance of each other. ${ }^{212}$

This had the direct consequence of rendering the Security Council virtually ineffective. Whenever there was a humanitarian crisis that demanded that the Security Council take action, the Security Council could not as one of the permanent members of the Security Council always exercised the right to veto the decision of the Security Council. Thus, the UN could not send forces to Uganda, Kampuchea when human catastrophes were being perpetrated.

\section{(a) Selection of Cases}

Most interventions during the 'Cold War' were basically for ideological purposes. As a result, I would discuss two interventions that nothing to do with the 'super powers' and were generally accepted as humanitarian, even if the intervening states were believed to have some other motives for intervening.

\section{(i) India in East Bengal (Bangladesh), 1971}

\footnotetext{
${ }^{212}$ The civil war in Angola is a good example. Here the MPLA (which was later recognized as the government) was self-declared Marxist-Leninist, while the rebel UNITA was Maoist. Nevertheless, while the Soviet Union gave support to the MPLA, the USA gave a massive support to UNITA. See http://www.emulateme.com/history/anghist.htm
} 
India gained independence from Great Britain in 1947. Two separate nations came into existence with the withdrawal of Great Britain from the Indian peninsula, namely India and Pakistan. ${ }^{213}$ Pakistan was a nation divided geographically and ethnically into two entities, West Pakistan and East Pakistan (also known as West and East Bengal). ${ }^{214}$ These two communities had very different characteristics ${ }^{215}$ and only enmity for India and a shared religion united them. $^{216}$

By 1970, the lesser populated West Pakistanis had gained political and economic control of East Pakistan, creating a condition of serious unrest in the East. ${ }^{217}$ General elections were held in December 1990. The Awami League, an opposition party in East Pakistan won majority of the seats in the National Assembly and demanded more autonomy for the East. ${ }^{218}$ This did not go down well with the central government and President Yahya Khan decided to postpone the National assembly indefinitely. ${ }^{219}$ The existing crisis in East Pakistan was then aggravated. Sheikh Mujibur Rahman, the Awami League leader, issued a “Declaration of Emancipation” on March 23, 1971. 220

On March 25, 1971, the West Pakistani army struck East Pakistan and started an indiscriminate killing of unarmed civilians, Bengalis and Hindus, burning of homes and other property. ${ }^{221}$ The West Pakistani army killed an estimated one million people during its campaign,

\footnotetext{
${ }^{213}$ Fernando Teson, Humanitarian Intervention, 200 ( $2^{\text {nd }}$ ed. 1997).

${ }^{214}$ Id.

${ }^{215} \mathrm{Id}$.

${ }^{216}$ Douglas Eisner, Humanitarian Intervention in the Post-Cold War Era, 11 B. U. Int'l L. J. 195, 199 (1993).

217 Ved P. Nanda, Tragedies in Northern Iraq, Liberia, Yugoslavia, and Haiti-Revisiting the Validity of Humanitarian Intervention Under International Law-Part I. 20 Denv. J. Int'l L. 305, 315 (1992).

${ }^{218}$ Id.

${ }^{219}$ Fernando Teson, Humanitarian Intervention, 202 ( $2^{\text {nd }}$ ed. 1997).

${ }^{220} \mathrm{Id}$.

${ }^{221}$ Id.
} 
particularly the minority Hindu population. ${ }^{222}$ An estimated ten million people fled to India as a result of the massacres, causing the country tremendous hardship. ${ }^{223}$

Border incidents began to occur and the relationship between India and Pakistan became tense. On December 3, 1971, India attacked Pakistan and formally recognized an independent state of Bangladesh on December 6, 1971. India defeated the West Pakistani army and the war lasted twelve days. ${ }^{224}$ India initially justified the intervention on humanitarian reasons, and the Indian representative to the United Nations declared thus: "we have ... absolutely nothing but the purest of motives and the purest intentions: to rescue the people of East Bengal from what they are suffering.”225 However, this 'humanitarian' rationale was later changed to self-defense as India claimed Pakistan had attacked it during the border skirmishes between the two nations. ${ }^{226}$

It has been argued that India's intervention was not a legitimate case of humanitarian intervention and therefore does not support the legality of humanitarian intervention. First, it is claimed that there is little doubt about the fact that India had more selfish motives for intervening rather than humanitarian. It is claimed that the splitting up of Pakistan, a powerful rival, enhanced India's own security. ${ }^{227}$ However, this reason in itself does not detract from it being a case of humanitarian intervention and supporting the existence of the rule because a valid humanitarian intervention need not be motivated solely by human rights concern since it is difficult, if not impossible, to determine all the motives of state action. ${ }^{228}$

\footnotetext{
${ }^{222}$ Douglas Eisner, Humanitarian Intervention in the Post-Cold War Era, 11 B. U. Int’l L. J. 195, 202 (1993).

${ }^{223}$ Natolino Ronzitti, Rescuing Nationals Abroad Through Military Coercion and Intervention on the Grounds of Humanity 95 (1985).

${ }^{224}$ Fernando Teson, Humanitarian Intervention 204 ( $2^{\text {nd }}$ ed. 1997).

${ }^{225}$ U. N. Doc. S/PV. 1606 (1971). Quoted in T. M. Franck and N. S. Rodley, After Bangladesh: The Law of Humanitarian Intervention by Military Force, 67 Am. J. Int'l L. 275, 276 (1973).

${ }^{226}$ N. J. Wheeler, Saving Strangers: Humanitarian Intervention in International Society 62 (Oxford University Press, 2000).

${ }^{227}$ Douglas Eisner, Humanitarian Intervention in the Post-Cold War Era, 11 B. U. Int'l L. 195, 202 (1993).

${ }^{228}$ Id.
} 
India's action drew sharp criticisms from the U.N. In a vote in the General Assembly on the lawfulness of India's action, a massive one-hundred and four nations declared India's action an unlawful violation of sovereignty ${ }^{229}$ and called on India to withdraw its troops from East Pakistan. $^{230}$

Again, it has been argued that the fact that India changed its justification from 'humanitarian' to self-defense means that India acknowledged that humanitarian intervention was not legal. I agree with Akehurst's argument that India's change of mind signaled their 'realization that humanitarian intervention was not a sufficient justification for the use of force'. ${ }^{231}$ However, Teson argues that the important point is not whether changed its justification or not, but whether a look at the whole situation depicts one that warranted foreign intervention on grounds of humanity. Bazyler claims that India's "course of action in the Bangladesh situation probably constitutes the clearest case of forceful individual humanitarian intervention in this century," and argues that the intervention supports the doctrine. ${ }^{232}$ It must be noted that an act may be illegal at the time it is done but may mark the beginning of a new rule of customary international law and therefore the Indian intervention is significant, whichever way one looks at it. I support the view that at the time India intervened in Pakistan they believed that humanitarian intervention was not legal and that is why they changed their justification from one of 'humanitarian' to self-defense.

\footnotetext{
${ }^{229}$ U. N. GAOR, 26th Sess., 2003 mtg. at 44-45, U. N. Doc. A/PV. 2003.

${ }^{230}$ G. A. Res. 2793 (XXVI) (Dec. 7, 1971).

${ }^{231}$ M. Akehurst, The Use of Force to Protect Nationals Abroad. Quoted in A. C. Arend and R. J. Beck, International Law and the Use of Force 119 (London, Routledge, 1993).

${ }^{232}$ Michael Bazyler, Reexamining the Doctrine of Humanitarian Intervention in Light of the Atrocities in Kampuchea and Ethiopia, 23 Stan. J. Int'l L. 547, 548 (1987).
} 


\section{(ii) Tanzania in Uganda, 1979}

The Idi Amin government of Uganda committed widespread atrocities and massive human rights violations against its own citizens during its reign from 1971 to $1979 .^{233}$ The government of Uganda executed approximately three-hundred thousand people during this period. ${ }^{234}$ Evidence of public executions, rape and torture was discovered by the Amnesty International which subsequently characterized the regime’s human rights as atrocious. ${ }^{235}$

During this period, border skirmishes between Uganda and its neighbor, Tanzania, increased hostilities between the two countries. In October 1978, Ugandan troops invaded Tanzanian territory and occupied the Kagera salient, an area located between the UgandaTanzania border and the Kagera River. ${ }^{236}$ Amin subsequently declared the annexation of the territory north of the Kagera salient on November $1 .^{237}$ Tanzania's President, Nyerere, considered the annexation tantamount to war and vowed to act against vigorously against the Ugandan troops. ${ }^{238}$

On November 15, 1979, Tanzania launched an offensive against Uganda, operating from the Southern Bank of the Kagera River. ${ }^{239}$ The Ugandans happily welcomed the Tanzanian troops, Amin threatened in a broadcast to punish all who supported the enemy. ${ }^{240}$ The Tanzanian military eventually toppled the Amin government, putting an end to the atrocities that the Ugandan people were suffering.

\footnotetext{
${ }^{233}$ Thomas M. Franck, Of Gnats and Camels: Is there a Double Standard at the United Nations? , 78 Am. J. Int'l L. 811, 825 (1984).

${ }^{234}$ Michael Bazyler, Reexamining the Doctrine of Humanitarian Intervention in Light of the Atrocities in Kampuchea and Ethiopia, 23 Stan. J. Int'l L. 547, 590 (1987).

${ }^{235}$ Amnesty International, Human Rights in Uganda, Report, June 1978, Doc. AFR 59/05/78.

${ }^{236}$ Fernando Teson, Humanitarian Intervention 179 ( $2^{\text {nd }}$ ed. 1997).

${ }^{237}$ Id.

${ }^{238} \mathrm{Id}$

${ }^{239}$ Id. at 180 .

${ }^{240}$ Id. at 181.
} 
It has been argued that Tanzania's primary motive for the invasion was self-interest, ${ }^{241}$ especially because Tanzania justified the invasion in self-defense to the initial Ugandan aggression. ${ }^{242}$ President Nyerere of Tanzania declared thus after the invasion, "[the] war between Tanzania and Idi Amin’s regime in Uganda was caused by the Ugandan army's aggression against Tanzania and Idi Amin's claim to have annexed part of Ugandan territory. There was no other cause for it.",243

That notwithstanding, humanitarian concerns played a role in the intervention. The savage and barbaric acts committed by the Amin government against its people were no secrets and President Nyerere's derision for the Amin regime's atrocities is well-documented. ${ }^{244}$ Nyerere had earlier described the Amin regime as a government of "thugs" which the Ugandans had a right to overthrow. ${ }^{245}$ The Tanzanian foreign minister described the successful toppling of Amin's government as 'a tremendous victory for the people of Uganda and a singular triumph for freedom, justice and human dignity,. ${ }^{246}$

In assessing the validity of Tanzania's intervention with regards to the legality of unilateral humanitarian intervention, it is important to note that the world community generally reacted favorably to it. ${ }^{247}$ Tanzania was never seriously reprimanded for the intervention though some claimed the invasion violated international law. ${ }^{248}$ It is argued that the generally favorable reaction by the world community to the invasion demonstrate a tacit acceptance of the

241 Ved P. Nanda, Tragedies in Northern Iraq, Liberia, Yugoslavia, and Haiti-Revisiting the Validity of Humanitarian Intervention Under International Law-Part I. 20 Denv. J. Int'l L. 305, 320 (1992).

${ }^{242}$ Id.

243 See A. C. Arend and R. J. Beck, International Law and the Use of Force 124 (London, Routledge, 1993).

${ }^{244}$ Douglas Eisner, Humanitarian Intervention in the Post-Cold War Era, 11 B. U. Int'l L. J. 195, 202 (1993).

${ }^{245}$ Id.

246 See A. C. Arend and R. J. Beck, International Law and the Use of Force 124 (London, Routledge, 1993).

${ }^{247}$ Fernando Teson, Humanitarian Intervention: An Inquiry Into Law and Morality 166 (1988).

${ }^{248}$ Thomas M. Franck, Of Gnats and Camels: Is there a Double Standard at the United Nations? , 78 Am. J. Int'l L. 811, 816 (1984). 
humanitarian intervention principle. ${ }^{249}$ Teson concludes: “This is surely tantamount to saying that the international community as a whole recognized in this case the primacy of a modicum of human dignity over sovereignty. "250 However, the fact that Tanzania never officially claimed humanitarian reasons as part of the justification for the invasion detracts from the precedential value of this case with respect to the legality of humanitarian intervention.

\section{Interventions After the Cold War,1990-Present}

The early 1990's witnessed changes in the affairs of the international community, and these were so profound that they would have been unimaginable only a few years before. ${ }^{251}$ The disintegration of the Soviet Union and the 'Eastern Bloc' with it, and the end of the East-West hostilities, created a new international political climate. Finally, the SC could perhaps function the way the drafters of the Charter planned. Lillich rightly expressed the new optimism thus:

“The conclusion of the Cold War ... presented a once-in-a-lifetime opportunity for the nations of the world, acting individually, collectively and through the UN ...to help achieve two principal purposes of the UN: the maintenance of international peace and security and the promotion and encouragement of human rights and fundamental freedoms."252

\section{(a) Selection of Cases}

As a result of the restored functioning of the UN, the majority of interventions after 1990 has been authorized by the Security Council, and therefore has to be dismissed from the

\footnotetext{
${ }^{249}$ Fernando Teson, Humanitarian Intervention: An Inquiry Into Law and Morality 170 (1988).

${ }^{250} \mathrm{Id}$.

251 See Abiew, The Evolution of the Doctrine and Practice of Humanitarian Intervention 137 (Hague, Kluwer Law International, 1992).

252 R. B. Lillich, The Role of the UN Security Council in Protecting Human Rights in Crisis Situations: UN Humanitarian Intervention in the Post- Cold War World, 3 Tulane J of Int \& Comp. L., 1, 2 (1994). Quoted in Abiew ,The Evolution of the Doctrine and Practice of Humanitarian Intervention (Hague, Kluwer Law International, 1992) 137
} 
subsequent investigation. ${ }^{253}$ Therefore, I will only assess a few cases of unilateral humanitarian intervention.

\section{(i) USA, UK and France in Iraq, 1991}

The Kurdish population in Iraq has claimed a right to sovereign status since the late $19^{\text {th }}$ century. They are however divided between Iraq, Iran, Syria and Turkey, and have been persecuted to some extent by all these states at one point in time or another. ${ }^{254}$ In 1985, Saddam Hussein’s Iraqi government started systematically destroying Kurdish villages and even used chemical weapons against some settlements, killing as many as 10,000 Kurds. ${ }^{255}$

In the aftermath of the Persian Gulf War in February 1991, Kurdish rebels took advantage of the unstable political situation and made significant military advances. ${ }^{256}$ However, their military gains were short-lived when Iraqi forces again started attacking Kurdish villages and massacred the civilian population on a large scale. An estimated 1.5 million of a total of 3-4 million of the Kurdish population fled into Turkey and Iran. ${ }^{257}$ The SC subsequently on April 3, 1991 passed Resolution 668, stating that the SC: "Condemns the repression of the Iraqi civil population... Demands that Iraq, as a contribution to removing the threat to international peace

\footnotetext{
${ }^{253}$ I am excluding that from the subsequent investigation because interventions authorized by the Security Council are obviously legal under the UN Charter. Besides, it does not form part of the topic of enquiry which is unilateral humanitarian intervention.

${ }^{254}$ See Stromseth J.E., Iraq's Repression of its Civilian Population: Collective Responses and Continuing Challenges in Damrosch, Enforcing Restraint: Collective Intervention in Internal Conflicts 77, 80 ff (New York, Council on Foreign Relations, 1993).

${ }^{255}$ See Abiew, The Evolution of the Doctrine and Practice of Humanitarian Intervention 146 (Hague, Kluwer Law International, 1992).

${ }^{256}$ See J. E. Stromseth, Iraq's Repression of its Civilian Population: Collective Responses and Continuing Challenges in Damrosch, Enforcing Restraint: Collective Intervention in Internal Conflicts 83 (New York, Council on Foreign Relations, 1993).

${ }^{257}$ See Wheeler N.J., Saving Strangers: Humanitarian Intervention in International Society 141 (Oxford University Press, 2000). See also Abiew, The Evolution of the Doctrine and Practice of Humanitarian Intervention 148 (Hague, Kluwer Law International, 1992).
} 
and security in the region, immediately end this repression ... Appeals to all Member States and to all humanitarian organizations to contribute to these humanitarian relief efforts”. 258

This Resolution, though referred to a 'threat to international peace and security', it fell short of authorizing forceful measures under Chapter VII of the Charter. ${ }^{259}$ It does not mention any collective enforcement measures and does not expressly authorize any military intervention. ${ }^{260}$ The text was a compromise, passed with the least possible support, and it was clear that such an authorization would never have been accepted by China or the Soviet Union in the SC. ${ }^{261}$

However, later in the same month, USA, UK and France announced their plans of 'Operation Provide Comfort' to establish 'safe havens' and a 'no-fly-zone' in Northern Iraq. The then UN Secretary General, Perez de Cuellar, expressed concerns that without Iraq’s consent, their sovereignty would be violated, or 'consent would have to be sought from the Security Council’ ${ }^{262}$

Nevertheless, the proposed intervention by the USA, the UK and France commenced on April 16. According to President Bush of the USA, the operation was 'motivated by humanitarian concerns'. ${ }^{263}$ The UN Secretary General also acknowledged the importance of acting from a 'moral and humanitarian point of view' ${ }^{264}$ The British Foreign Minister, Douglas Hurd, stated that: "[W]e operate under international law. Not every action that a British Government or an American Government or a French Government takes has to be underwritten

\footnotetext{
${ }^{258}$ See the full text of Security Council Resolution 668.

${ }^{259}$ N. J. Wheeler, Saving Strangers: Humanitarian Intervention in International Society146 (Oxford University Press, 2000).

${ }^{260}$ P. Malanczuk, Humanitarian Intervention and the Legitimacy of the Use of Force 18 (Amsterdam, Het Spinhuis, 1993).

${ }^{261}$ N. J. Wheeler, Saving Strangers: Humanitarian Intervention in International Society146 (Oxford University Press, 2000).

${ }^{262}$ Quoted in Wheeler, supra at 156.

${ }^{263}$ Quoted in Wheeler, supra at 151.

${ }^{264}$ Id at 153.
} 
by a specific provision in a UN resolution provided we comply with international law. International law recognizes extreme humanitarian need” ${ }^{265}$

Shortly after the intervention, however, the allied countries tried to make the UN take responsibility for the operation. Iraqi consent was needed to make it legal and on April 18, an agreement was reached with Iraq concerning the presence of a limited number of UN troops as guards and the establishment of 100 civilian aid centers in Iraq. It is thus argued that Iraq consented in the intervention and it is therefore legal through consent. ${ }^{266}$

It is the view of this author that the argument that the intervention was carried out with the acquiescence of Iraq and therefore legal does not hold water. The facts are as simple as these. A large number of Allied Troops invaded Iraq and Iraq was only later forced to accept a limited UN presence. The initial intervention never had Iraqi consent and can only be seen as an intervention for humanitarian purposes. I posit that the view submitted by Malanczuk represents the true state of affairs with regard to the intervention. He stated that:

Resolution 688 by itself did not provide the legal basis [for the operation]. The legal significance of the allied action as to state practice, on the other hand, for the development of customary international law will become apparent only in a longer-term perspective. ${ }^{267}$

The allied intervention in Northern Iraq can be regarded as a case of humanitarian intervention. Though the members of the Allied Force made statements that sought to justify the intervention on humanitarian grounds, they never officially justified the intervention as such. In a memorandum to the British Foreign Affairs and Commonwealth Office, the legal counsel said

\footnotetext{
${ }^{265}$ Interview on BBC Radio on 19 August 1992, printed in United Kingdom Materials on International Law (1992) 63 BYIL 824

${ }^{266}$ See Wheeler N.J., Saving Strangers: Humanitarian Intervention in International Society (Oxford University Press, 2000), 154

${ }^{267}$ Malanczuk P., Humanitarian Intervention and the Legitimacy of the Use of Force 19 (Amsterdam, Het Spinhuis, 1993).
} 
that: "[T]he intervention in northern Iraq "Provide Comfort" was in fact, not specifically mandated by the United Nations, but the states taking action in northern Iraq did so exercise of the customary international law principle of humanitarian intervention".

Similar statements and sentiments were expressed by US officials. ${ }^{268}$ As indicated earlier, these statements were never official. That fact is a strong indicator that the Allied States did not view the principle of humanitarian intervention as legal at the time.

It's been argued however that the members of the Security Council, by staying silent about the operation, tacitly accepted the doctrine and acknowledged that such rules were part of customary law. ${ }^{269}$ The reason China and the Soviet Union were reluctant to pass a resolution permitting the use of force was allegedly just that they did not want to set a precedent limiting the principle of sovereignty. ${ }^{270}$

However, this author does not think it is right to construe the inaction on the part of the members of the Security Council as a tacit consent to the intervention by the Allied Forces. I think that importance should rather be attached to the expressed concerns of the members of the Security Council about the legality of humanitarian intervention, and not their failure to protest since the use of the veto makes the Security Council impotent at times.

In summary, the intervention in Northern Iraq cannot be seen as rendering unilateral humanitarian intervention legal in customary international law. There was no clear expression of opinio juris by the international community to that effect. But Wheeler notes that:

[T] hese caveats do not alter the fact that the safe havens marked a solidarist moment in the society of states. It is claiming too much to argue that the silence that greeted Western

\footnotetext{
${ }^{268}$ See Abiew, The Evolution of the Doctrine and Practice of Humanitarian Intervention 155 (Hague, Kluwer Law International, 1992).

${ }^{269}$ See Wheeler, Saving Strangers: Humanitarian Intervention in International Society 167 (Oxford University Press, 2000).

${ }^{270}$ Id at 144.
} 
action supports a new custom of humanitarian intervention, since international law requires that there be supporting opinio juris. Yet, by raising new humanitarian claims, the language of safe havens entered the normative vocabulary of the society of states. ${ }^{271}$

It is significant to note that though the members of the Allied Forces did not officially justify the action as one of humanitarian intervention, public statements by leading officials of the member states of the Allied Forces relied on humanitarian intervention.

\section{(ii) ECOWAS in Liberia, 1990}

In December 1989, the National Patriotic Front of Liberia (NPFL), led by Charles Taylor, invaded the country from La Cote D’Ivoire to overthrow a Samuel Doe regime guilty of massive human rights abuses in preceding years. ${ }^{272}$ By August 1990, the NPFL forces controlled most of the country while Doe still controlled Monrovia. The civil war raged on, with factions separating from both parties and adding to the chaos. All sides were reportedly murdering and torturing the civilian population, thousands faced starvation, and an estimated 1.3 million people were either fleeing the country or were internally displaced. ${ }^{273}$

The Economic Community of West African States (ECOWAS) became concerned and decided to intervene. The ECOWAS Standing Mediation Committee justified the intervention on the ground that "[T]here is a state of anarchy and total breakdown of Law and order in Liberia. ... These developments have traumatized the Liberian population and greatly shocked the people of the sub-region and the rest of the international community.,274

\footnotetext{
${ }^{271}$ Wheeler, Saving Strangers: Humanitarian Intervention in International Society 169 (Oxford University Press, 2000).

${ }^{272}$ See D. Wippman, Enforcing the Peace: ECOWAS and the Liberian Civil War in Enforcing Restraint: Collective Intervention in Internal Conflicts157 ff. (New York, Council on Foreign Relations, 1993).

${ }^{273}$ See Abiew, The Evolution of the Doctrine and Practice of Humanitarian Intervention $200 \mathrm{ff}$. (Hague, Kluwer Law International, 1992).

${ }^{274}$ Final Communiqué of the First Joint Meeting of the ECOWAS Standing Mediation Committee and the Committee of Five, Para. 6-9. Quoted in Abiew, supra at 206.
} 
On August 23, 1990, the ECOWAS Monitoring Group (ECOMOG) intervened. The NPFL and other factions that did not want any foreign interference in the conflict however soon attacked them. ${ }^{275}$ The ECOMOG succeeded in certain respects, e.g. in establishing a peace treaty in October 1991 that lasted somewhat longer than the previous ones. However, the fighting never ceased for long.

The SC passed a resolution on November 19, 1992 (resolution 788), where it stated:

Determining that the deterioration of the situation in Liberia constitutes a threat to international peace and security.... Recalling the provisions of Chapter VII of the Charter of the United Nations.... Recognising the need for increased humanitarian assistance.... Commends ECOWAS for its efforts to restore peace, security and stability in Liberia.... Requests the Secretary General to dispatch urgently a Special Representative to Liberia to evaluate the situation.... ${ }^{276}$

This resolution, like its predecessor, resolution 668 that was issued in the Iraqi case, did not authorize collective use of force. It is also significant to note that the ECOWAS intervention had long started before the resolution was passed. It was obvious some SC members were reluctant to authorize the use of force in yet another conflict area, as the aftermath of the Persian Gulf War had resulted in troubles in Somalia. ${ }^{277}$

The ECOWAS intervention can be regarded as a multilateral intervention motivated by humanitarian reasons. It has been claimed that 'the ECOWAS intervention in Liberia satisfies virtually every proposed test, and in many respects constitutes an excellent model [of humanitarian intervention]'. ${ }^{278}$ However, the real issue is whether the required opinio juris existed in order to grant it legal status under customary law?

\footnotetext{
${ }^{275}$ See Wippman, The Evolution of the Doctrine and Practice of Humanitarian Intervention (Hague, Kluwer Law International, 1992), 167.

${ }^{276}$ Security Council Resolution 788 of 19 November, 1992.

277 See Abiew, The Evolution of the Doctrine and Practice of Humanitarian Intervention 207 (Hague, Kluwer Law International, 1992).

${ }^{278}$ Wippman, The Evolution of the Doctrine and Practice of Humanitarian Intervention 179 (Hague, Kluwer Law International, 1992).
} 
Though the Security Council did not authorize the intervention, it commended ECOWAS for its efforts in Liberia, implicitly supporting the intervention. It has been argued that the members of the Security Council actually recognized the intervention as legal; but were avoiding creating a precedent that would allow frivolous violations of sovereignty in the future. ${ }^{279}$ This argument is however not tenable. The members of the Security Council could have authorized forceful measures at the outset but they did not, implicitly accepting the illegality of the use of force in such circumstances. This is further strengthened by the fact that they applauded ECOWAS for taking the initiative, meaning they recognized the fact that intervention was essential at the time.

However, the legal significance of the ECOWAS intervention with respect to the legality of unilateral humanitarian intervention is diminished by the fact that the SC sought to ratify the action and made it 'somewhat an action under the auspices of the United Nations'. It does not therefore offer much help in determining the legality of unilateral humanitarian intervention under customary law. It is however important to note that the SC supported the intervention.

\section{(iii) NATO in Kosovo, 1999}

With the final conclusion of the Dayton agreement on 21 November 1995 marking the end of the Bosnian war, one would have thought that the milestone for the achievement of peace for the region had arrived. ${ }^{280}$ However, this dream fizzled into thin air as the treatment meted out to the Kosovo-Albanians (Kosovars) by the Federal Republic of Yugoslavia (FRY) President, Slobodan Milosevic, had attained intolerable heights. He had suspended the rights of the

\footnotetext{
279 Abiew, The Evolution of the Doctrine and Practice of Humanitarian Intervention 208 (Hague, Kluwer Law International, 1992).

280 See G. Misha, The Balkans 1804-1999: Nationalism, War and the Great Powers 651ff. (London, Granta Books, 1999).
} 
Kosovars under the 1974 FRY constitution, and implemented strict segregation policies, which some described as an 'apartheid system in Kosovo'. ${ }^{281}$

During the $2^{\text {nd }}$ and $3^{\text {rd }}$ quarters of 1996, the Kosovo Liberation Army (Ushtria Climitare e Kosoves - the UCK) began making efforts to get international attention to the situation in Kosovo. $^{282}$ They thought that the pacifist boycott-policy was worsening their plight, by securing Serb control over a region where about $90 \%$ of the population was Albanian. ${ }^{283}$

The FRY army increased the tempo of attacks on the UCK, intensifying the conflict in the process. It was however not until early 1998 that the international community took a serious look at the situation. On March 31, 1998, the SC passed resolution 1160, in which it condemned 'the use of excessive force by Serbian police forces against civilians and peaceful demonstrations in Kosovo, as well as acts of terrorism by the Kosovo Liberation Army'. But this resolution did not prescribe any solution to the conflict, but did impose a weapons embargo and called on the parties to resolve the conflict 'through dialogue'.

The hostilities continued and it became clear in no time that the Serbs attacks on the UCK were resulting in the civilian population of Kosovo fleeing into Albania and Macedonia. The Security Council subsequently on September 23, 1998 passed resolution 119, stating as follows:

Affirming that the deterioration of the situation in Kosovo, Federal Republic of Yugoslavia, constitutes a threat to peace and security in the region.... Demands ...that the authorities of the Federal Republic of Yugoslavia and the Kosovo Albanian leadership take immediate steps to improve the humanitarian situation and to avert the impending humanitarian catastrophe. ${ }^{284}$

Although the situation was now widely regarded as a case falling under Chapter VII of the UN Charter, the demands made in the resolution were not backed by a threat of military

\footnotetext{
${ }^{281}$ See N.J. Wheeler, Saving Strangers: Humanitarian Intervention in International Society 257 (Oxford University Press, 2000).

${ }^{282}$ See generally G. Misha, supra.

${ }^{283}$ See Misha, supra $656 \mathrm{ff}$.

${ }^{284}$ Security Council Resolution 119 (1998).
} 
action. A clear authorization by the SC to use force was not feasible, as both China and Russia would veto any such proposal. ${ }^{285}$

The hostilities continued and the humanitarian concerns became more pressing. The NATO countries decided to take action. On 13 October 1998 they issued an activation order for air strikes if the Serbs did not stop their indiscriminate attacks on Kosovar settlements. ${ }^{286}$ In the last moment however, the NATO sent US Special Envoy Holbrooke to Belgrade, and he persuaded Milosevic to accept a cease-fire and the presence of some inspectors from the Organisation on Security and Cooperation in Europe (OSCE). This resulted in a cease-fire, albeit temporary.

This fragile cease-fire was again shattered when the UCK, which was left out of the OSCE agreement, refused to respect it. In retaliation, the FRY forces massacred 45 civilians in the village of Racak, an event that shocked the world community. ${ }^{287}$ NATO invited the parties to Rambouillet outside Paris in a last effort to secure peace. Here, the UCK agreed to drop their demand for total independence, and the FRY would in turn have to accept the presence of a NATO force in Kosovo. These terms were unacceptable to the Serbs, who began a new campaign of ethnic cleansing of Kosovo. ${ }^{288}$

The NATO countries made a last minute plea for restraint but Milosevic failed to oblige. Subsequently, NATO started launching air strikes against the FRY on March 23, 1999. The following rationales have been offered as possible justifications for NATO’s intervention, ${ }^{289}$

${ }^{285}$ See N.J. Wheeler, Saving Strangers: Humanitarian Intervention in International Society 206ff. (Oxford University Press, 2000).

${ }^{286}$ See B. Simma, NATO, the UN and the Use of Force: Legal Aspects (1990), 10 Eur. J. Int'l L. 1, 5 for the full text of the activation order.

${ }^{287}$ See D. Kritsiotis, The Kosovo Crisis and NATO's Application of Armed Force Against the Federal Republic of Yugoslavia, 49 Int'l C. L. Q. 330, 337 (2000).

${ }^{288}$ Id. at 339.

289 See N.J. Wheeler, Saving Strangers: Humanitarian Intervention in International Society 205 ff. (Oxford University Press, 2000). 
though most of them do not warrant any serious consideration in so far as the legality of the intervention is concerned.

First, that NATO’s credibility as a collective defense organization was at stake. However, this can obviously not serve as a legal justification for waging war under customary international law. ${ }^{290}$ This ground therefore has no importance on the issue of the legality of unilateral humanitarian intervention.

Second, it has been argued that the intervention was in conformity with SC resolutions. But since China and Russia obviously opposed to the intervention, both in the debate in the SC and when it was a fait accompli, this was also an evident misconception ${ }^{291}$ and does not help in resolving the issue of the legality of the intervention so far as the rules of customary law are concerned.

Perhaps, the rationale that generated the most debate was the one which sought to justify the action on humanitarian grounds. It was postulated that the action was aimed at averting an impending catastrophe. This is also the only basis on which the intervention can possibly be legal. Thus, the British Foreign Secretary stated in Parliament, "We were left with no other way of preventing the present humanitarian crisis from becoming a catastrophe than by taking military action to limit the capacity of Milosevic’s army to repress the Kosovar Albanians”. 292

The importance of this intervention with regards to the legality of unilateral humanitarian intervention can be assessed from the reaction of the world community after the action. Most western states supported the action of NATO. Britain reiterated its previous justification of the

\footnotetext{
${ }^{290}$ See G. Misha, The Balkans 1804-1999: Nationalism, War and the Great Powers 657 (London, Granta Books, 1999).

${ }^{291}$ See Wheeler, Saving Strangers: Humanitarian Intervention in International Society 267 (Oxford University Press, 2000).

${ }^{292}$ Statement by Foreign Secretary Robin Cook in the House of Commons, 25 March, 1999. Quoted in Wheeler, Saving Strangers: Humanitarian Intervention in International Society 265 6(Oxford University Press, 2000).
} 
Iraqi intervention, and argued that humanitarian intervention was legal under customary international law. ${ }^{293}$ On the other hand, a Chinese official characterized the operation as 'absolute gunboat diplomacy', 294 and the Russian UN Ambassador stated that "[W]hat is in the balance now is the question of law and lawlessness. It is a question of either reaffirming the commitment of one's country and people to the basic principles and values of the United Nations Charter, or tolerating a situation I which gross force dictates realpolitik”. ${ }^{295}$

On March 26, 1999, Russia, with the support of India and Belarus, presented a draft resolution condemning the operation as unlawful under the UN Charter. Significantly, the draft resolution was defeated by a vote of twelve, among them six non-western countries, to three. ${ }^{296}$ For the first time, the members of the Security Council did not vote to condemn the use of force for a humanitarian purpose. ${ }^{297}$ Moreover, the UN Secretary-General Kofi Annan expressed limited support for the intervention, ${ }^{298}$ when he stated in 1999:

[T]his year's conflict in Kosovo raised equally important questions about the consequences of action without international consensus and clear legal authority... On the one hand is it legitimate for a regional organization to use force without a UN mandate? On the other, is it permissible to let gross and systematic violations of human rights, with grave humanitarian consequences, continue unchecked? ${ }^{299}$

Finally, 'no strong opposition.... emerged in the majority of Member States of the United Nations'. ${ }^{300}$ The legal significance of the case stems from the fact that it was no longer just the 'exaggeration of jurists sympathetic to humanitarian intervention, but, rather, the real working

${ }^{293}$ See Kriotsiotis, The Kosovo Crisis and NATO's Application of Armed Force Against the Federal Republic of Yugoslavia, 49 Int'l C. L. Q. 330, 340 (2000).

${ }^{294}$ Financial Times (London), 11 May, 1999. Quoted in Kritsiotis Id. at 346.

${ }^{295}$ Russian delegate in SC debate, 26 March 1999. Quoted in Wheeler, Saving Strangers: Humanitarian Intervention in International Society 279 (Oxford University Press, 2000).

${ }^{296}$ See Wheeler, Saving Strangers: Humanitarian Intervention in International Society 280 (Oxford University Press, 2000).

${ }^{297}$ See Kritsiotis, The Kosovo Crisis and NATO's Application of Armed Force Against the Federal Republic of Yugoslavia, 49 Int'l C. L. Q. 330, 347(2000).

${ }^{298}$ Id.at 348.

${ }^{299} \mathrm{http}: / /$ www.ploughshares.ca/content/WORKING\%20PAPERS/wp012.html

300 A. Cassese, Ex Injuria Ius Orbitur: Are We Moving to Towards International Legitimization of Forcible Humanitarian Countermeasures in the World Community? 10 Eur. J. Int'l L. 23, 28 (1999). 
and practice of States, ${ }^{301}$ as it was expressed in the UN fora, which supported the doctrine of humanitarian intervention.

\section{CONCLUSION: STATUS OF UNILATERAL HUMANITARIAN INTERVENTION UNDER CUSTOMARY INTERNATIONAL LAW}

A critical assessment of the cases of unilateral humanitarian interventions discussed above indicates that the doctrine is becoming more and more acceptable to the majority of states in the world. The invasion of Iraq by the UK, France and US received very little support from the community of states. Even though, the UK, especially sought to rely on customary law rules permitting humanitarian intervention, it is clear that the opinio juris needed to support a rule of customary international law was absent.

The subsequent cases however seems to have gained some support from the international community, and especially, from the UN. The UN commended the ECOWAS for their intervention in Liberia in a number of resolutions. Even though NATO did not enjoy an overwhelming support from the UN as the ECOWAS, the comprehensive manner in which the SC rejected a proposed draft legislation, which sought to declare the intervention legal, offers NATO some support from the world body. The UN Secretary General himself offered implicitly offered support to NATO when he questioned thus: “... On the other, is it permissible to let gross and systematic violations of human rights, with grave humanitarian consequences, continue unchecked?’302

It is clear that with the support received by the ECOWAS and NATO in their respective interventions for humanitarian purposes, there is in transition a rule of customary international law that would permit unilateral humanitarian intervention. The rule is however not yet fully

\footnotetext{
${ }^{301}$ Kritsiostis, The Kosovo Crisis and NATO's Application of Armed Force Against the Federal Republic of Yugoslavia, 49 Int'l C. L. Q.330, 358 (2000).

302 http://www.ploughshares.ca/content/WORKING\%20PAPERS/wp012.html
} 
crystallized and therefore does not form part of the body of rules recognized as belonging to the customary international law tradition. 


\section{CHAPTER 5}

\section{CONCLUSIONS}

The doctrine of unilateral humanitarian intervention is important and morally necessary in today's world. It is pathetic to allow human beings to suffer without any help just because of legal theories. Unfortunately, the rules of international law presently do not permit unilateral humanitarian interventions.

I must quickly point out that notwithstanding the important role of the doctrine; it is a doctrine that would be abused if a proper criterion were not put in place to regulate its use. Despite the possibility of abuse, the doctrine is very vital to the protection of human rights and world peace and must be maintained. However, it is essential that a proper formula be put in place to regulate its use.

The best way to put in place a system that would ensure that the doctrine is maintained and properly regulated is for the UN draft guidelines on humanitarian interventions. The provisions of the UN Charter should be amended to permit humanitarian interventions when stated conditions are met. The UN has to put in place a criterion that must be met before humanitarian interventions can be undertaken. I acknowledge it would be difficult to achieve a consensus at the UN since some states still prefer 'absolute sovereignty'. However, the difficulty is not insurmountable.

I humbly suggest that the following measures may be of assistance in any coherent theory that seeks to regulate humanitarian interventions. First, the Security Council should be notified by a state contemplating humanitarian intervention. 
No state should intervene unilaterally until the SC fails to act within a reasonable time after it has been notified of the situation warranting intervention.

Second, it must be established that the violations of human rights in the target state is significant and amount to the level that 'shocks the conscience of the world'. The rights violated should be the most basic of human rights. Thus, human rights violations that are not so serious should not warrant any unilateral intervention.

Third, all measures short of the use of force should have been employed in trying to curtail the human rights violations before humanitarian interventions should be contemplated. Thus, the state contemplating humanitarian intervention must furnish the SC with measures not involving the use of armed force that has been taken in order to end the atrocities. These measures should have proved to be insufficient or there must be strong reasons to believe that these measures will not be fruitful.

Fourth, the intervening country’s own human rights record must be scrutinized to ensure that countries with bad human rights records are prohibited from undertaking humanitarian interventions. Further, proper scrutiny should be undertaken by the Security Council to ensure that the overriding objective for the intervention is to curtail human rights violations.

Finally, the length of the intervention must not be longer than necessary to bring an end to the human rights violations. Thus, the intervening state must promptly leave the target state as soon as it can be proved that the task of eradicating the human rights violations has been accomplished.

If all these suggestions are implemented, I believe the concerns regarding the abuse of humanitarian interventions would be minimized and the doctrine would be generally accepted. There is no doubt that the doctrine is necessary in today's world. 


\section{BIBLIOGRAPHY}

\section{LAW REVIEWS}

1. Michael Reisman, "Sovereignty and Human Rights in Contemporary International Law," 84 Am. J. Int’l L. 867 (1990).

2. Stephen D. Krasner, “Compromising Westphalia”, 20 Int’l Sec. 115 (1995-6).

3. George R. Wright, A Contemporary Theory of Humanitarian Intervention, 4 Fla. Int'l L. J. 435 (1989).

4. Steve G. Simon, The Contemporary Legality of Humanitarian Intervention, 24 Cal. W. Int'l L. J. 117, 118 (1993).

5. Laura Geissler, The Law of Humanitarian Intervention and the Kosovo Crisis, 23 Hamline L. Rev. 323, 325 (2000).

6. Thomas M. Franck, Of Gnats and Camels: Is there a Double Standard at the United Nations? , 78 Am. J. Int'l L. 811, 825 (1984).

7. Ved P. Nanda, Tragedies in Northern Iraq, Liberia, Yugoslavia, and Haiti-Revisiting the Validity of Humanitarian Intervention under International Law-Part I. 20 Denv. J. Int'l L. 305, 320 (1992).

8. Byron F. Burmester, On Humanitarian Intervention: The New World Order and Wars to Preserve Human Rights, 1994 Utah L. Rev. 269 (1994).

9. Douglas Eisner, Humanitarian Intervention in the Post-Cold War Era, 11 B. U. Int'l L. J. 195, 202 (1993).

10. Michael J. Bazyler, Reexamining the Doctrine of Humanitarian Intervention in Light of the Atrocities in Kampuchea and Ethiopia, 23 Stan. J. Int'l L. 547, 589 (1987).

11. John N. Moore, Grenada and the International Double Standard, 78 Am. J. Int'l L. 145, 148 (1984).

12. J.L. Kunz, Bellum Justum and Bellum Legale, 45 Am. J. Int’l L. 528, 532 (1951).

13. Verwey, Humanitarian Intervention under International Law 32 Neth. I. L. R. 357, 399 (1985). 
14. C.G. Fenwick, Intervention: Individual and Collective 39 Am. J. Int'l L. 645, 650 (1945).

15. Sornarajah, International Colonialism and Humanitarian Intervention, 11 Ga. J. Int'l \& Comp. L. 45, 57 (1981).

16. J. P. L. Fonteyne, The Customary International Law Doctrine of Humanitarian Intervention, 4 Cal. W. Int'l L. J. 203, 234 (1974).

17. Fairley, "State Actors, Humanitarian Intervention and International Law: Reopening Pandora’s Box,” 10 Ga. J. Int’l \& Comp. L. 29 (1980).

18. Tom Farer, “The Regulation of Foreign Intervention in Civil Armed Conflict,” 142 R. C. A. D. I. 291 (1974).

19. Franck \& Rodley, "After Bangladesh: The Law of Humanitarian Intervention by Military Force,”67 Am. J. Int'l. L. 275 (1973).

20. Shen Jianming, The Non-Intervention Principle and Humanitarian Interventions Under International Law, 7 Int'l Legal Theory 1(2001).

21. Reisman, “Humanitarian Intervention and Fledgling Democracies,” 18 Fordham Int'l L. J. 794 (1995).

22. D’Amato, “The Invasion of Panama Was a Lawful Response to Tyranny,” 84 Am. J. Int'l L. 516 (1990).

23. Oscar Schacter, International Law: The Right of States to Use Armed Force, 82 Mich. L. Rev. 1620, 1620 (1984).

24. Edward Gordon, Article 2 (4) in Historical Context, 10 Yale J. Int'l L. 270, 275 (1985).

25. T. Modibo Ocran, The Doctrine of Humanitarian Intervention in Light of Robust Peacekeeping, 25 B.C. Int'l \& Comp. L. Rev.1, 14-15 (2002).

26. Oscar Schacter, Just War and Human Rights, 1 Pace Y.B. Int’l L. 1, 4 (1989).

27. Antonio Cassese, "Ex Iniuria Ius Oritur: Are We Moving Towards International Legitimization of Forcible Humanitarian Countermeasures in the World Community?" 10 Eur. J. Int’l L. 23, 24(1999).

28. McDougal \& Reisman, "Rhodesia and the United Nations: The Lawfulness of International Concern,” 62 Am. J. Int'l. L. 1, 15 (1968).

29. Farooq Hassan, Realpolitik In International Law: After Tanzanian-Ugandan Conflict “Humanitarian Intervention” Reexamined, 17 Williamette L. Rev. 859, 881 (1981). 
30. Michael Reisman, Criteria for the Lawful Use of Force in International Law, 10 Yale J. Int’l L. 279 (1985).

31. Jean-Pierre L. Fonteyne, The Customary International Law Doctrine of Humanitarian Intervention, 4 Cal. W. Int’l L.J. 203, 257 (1974).

32. B. Simma, NATO, the UN and the Use of Force: Legal Aspects 10 Eur. J. Int'l L. 1, 5 (1990)

33. D. Kritsiotis, The Kosovo Crisis and NATO's Application of Armed Force Against the Federal Republic of Yugoslavia, 49 Int'l C. L. Q. 330, 337 (2000).

34. A. Cassese, Ex Injuria Ius Orbitur: Are We Moving to Towards International Legitimization of Forcible Humanitarian Countermeasures in the World Community? 10 Eur. J. Int'l L. 23, 28 (1999).

35. Mary Ellen O’Connell, “The UN, NATO, and International Law after Kosovo,” 22 Hum. Rts. Q. 57, 82 (2000).

36. R. B. Lillich, The Role of the UN Security Council in Protecting Human Rights in Crisis Situations: UN Humanitarian Intervention in the Post- Cold War World, 3 Tulane $\mathrm{J}$ of Int'l \& Comp. L., 1, 2 (1994).

\section{BOOKS}

1. Francis Abiew, The Evolution of the Doctrine and Practice of Humanitarian Intervention (The Hague: Kluwer, 1999).

2. Louis Henkin, International Law: Politics and Values 9-10 (London: Martinus Nijihoff, 1995).

3. Francis Hinsley, Sovereignty 126 (London: Basic Books, 1966).

4. Fernando R. Teson, Humanitarian Intervention 133 (2 ${ }^{\text {nd }}$ ed. 1997).

5. Ellery Stowell, International Law 349 (1931).

6. Fernando R. Teson, Humanitarian Intervention: An inquiry into Law and Morality 5 (1988).

7. A. C. Arend and R. J. Beck, International Law and the Use of Force 113-4 (London, Routledge, 1993).

8. Aristotle, The Ethics of Aristotle: The Nichomachean Ethics 20 (1953). 
9. Dunoff et al, International Law: Norms, Actors, Process; A Problem Oriented Approach 827 (2002).

10. Thomas Aquinas, Summa Theologica II.

11. F. Suarez, De Bello (1583).

12. A. Gentili, De Jure Belli Libri Très I.

13. M. D. A. Freeman, Lloyd's Introduction to Jurisprudence 100 (London, Sweet \& Maxwell, $6^{\text {th }}$ ed. 1994).

14. H. Grotius, De Jure Belli ac Pacis Prolegomena, para 11 (1625).

15. L.R.B. Walters, Five Classic Just -War Theories: A Study in the Thought of Thomas Aquinas, Victoria, Suarez, Gentili, and Grotius 353 (Michigan, University Films, 1971).

16. N. Machiavelli, The Prince (1513).

17. Ian Brownlie, International Law and the Use of Force by States 20 (Oxford, Clarendon Press, 1963).

18. E. de Vattel, Droit des Gens (1758).

19. R. Phillimore, Commentaries upon International Law VIII, 77 (Butterworth, $3^{\text {rd }}$ ed. 1885).

20. Harris D.J., Cases and Materials on International Law 895 (London, Sweet \& Maxwell, 1998).

21. B.V.A. Roling, The Use of Force by States in The Current Legal Regulation of the Use of Force 4 (A. Cassese ed. 1986).

22. M. Walzer, Just and Unjust Wars 104 (New York, Basic Books, $2^{\text {nd }}$ ed. 1992).

23. L.F.L. Oppenheim, International Law- A Treatise-8th 312 (ed. by H. Lauterpacht), London, Longmans, Green \& Co. (1955).

24. John Rawls, “The Law of Peoples,” (1993).

25. Ian Brownlie, Principles of Public International Law, 7 (6 ${ }^{\text {th }}$ ed. 2003).

26. Rosalyn Higgins, The development of International Law through the Political Organs of the United Nations 183 (Oxford University Press, Oxford, 1963). 
27. Julius Stone, Aggression and world Order: A Critique of United Nations World Theories of Aggression, 95 (Stevens, London, 1958).

28. Anthony D’Amato, International Law: Process and Prospect 59 (1987).

29. Michael Reisman \& Myres S. McDougal, Humanitarian Intervention to protect the Ibos, in Humanitarian Intervention and the United Nations 167 (Richard B. Lillich ed.).

30. Tom J. Farer, An Inquiry into the Legitimacy of Humanitarian Intervention, in Law and Force in the New International Order 185, 190 (Lori F. Damrosch \& David J. Scheffer eds. 1991).

31. Louis Henkin, The Use of Force: Law and U.S. Policy, in Right v. Might 38 (L. Henin et al. eds. 1991).

32. H. Lauterpacht, International Law and Human Rights 145-6 (1986).

33. A. H. Robertson \& J.G. Merrills, Human Rights in the World 24 (1989).

34. P. Jessup, A Modern Law of Nations 170-71 (1948).

35. Lillich, "Humanitarian Intervention: A Reply to Ian Brownlie and a Plea for Constructive Alternatives," in Law and Civil War in the Modern World 229 (J. N. Moore ed., 1974).

36. Rebecca M.M. Wallace, International Law, 9 ( $3^{\text {rd }}$ ed. 1997).

37. Mark E. Villiger, Customary International Law and Treaties, 4 (1985).

38. Anthony D’Amato in The Concept of Custom in International Law 88 (1971).

39. Stromseth J.E., Iraq's Repression of its Civilian Population: Collective Responses and Continuing Challenges in Damrosch, Enforcing Restraint: Collective Intervention in Internal Conflicts 77, 80 ff (New York, Council on Foreign Relations, 1993).

40. P. Malanczuk, Humanitarian Intervention and the Legitimacy of the Use of Force 18 (Amsterdam, Het Spinhuis, 1993).

41. D. Wippman, Enforcing the Peace: ECOWAS and the Liberian Civil War in Enforcing Restraint: Collective Intervention in Internal Conflicts157 ff. (New York, Council on Foreign Relations, 1993).

42. G. Misha, The Balkans 1804-1999: Nationalism, War and the Great Powers 651ff. (London, Granta Books, 1999). 
43. Natolino Ronzitti, Rescuing Nationals Abroad Through Military Coercion and Intervention on the Grounds of Humanity 95 (1985).

\section{WEB MATERIALS}

1. http://www.iciss.ca/menu-en.asp

2. http://www.emulateme.com/history/anghist.htm

3. http://www.ploughshares.ca/content/WORKING\%20PAPERS/wp012.html

\section{NEWS AND PERIODICALS}

1. Amnesty International, Human Rights in Uganda, Report, June 1978, Doc. AFR 59/05/78.

2. Yearbook of the International Law Commission II 368 ff. (1950).

3. The Work of the International Law Commission 42.

4. Interview on BBC Radio on 19 August 1992.

5. Financial Times (London), 11 May, 1999. 